\title{
Design, synthesis and evaluation against Mycobacterium tuberculosis of azole piperazine derivatives as dicyclotyrosine (CYY) mimics
}

\author{
Hend A.A. Abd El-wahab ${ }^{\mathrm{a}, \mathrm{b}}$, Mauro Accietto ${ }^{\mathrm{a}, \mathrm{c}}$, Leonardo B. Marino ${ }^{\mathrm{d}}$, Kirsty J. McLean ${ }^{\mathrm{e}}$, Colin W. Levy ${ }^{\mathrm{e}}$, \\ Hamdy M. Abdel-Rahman ${ }^{\mathrm{b}}$, Mahmoud A. El-Gendy ${ }^{\mathrm{b}}$, Andrew W. Munro ${ }^{\mathrm{e}}$, Ahmed S. Aboraia ${ }^{\mathrm{b}}$, \\ Claire Simons ${ }^{\mathrm{a}, *}$
}

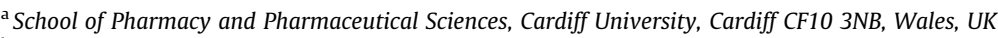

${ }^{\mathrm{b}}$ Department of Medicinal Chemistry, Faculty of Pharmacy, Assiut University, Assiut 71526, Egypt

${ }^{\mathrm{c}}$ Department of Life Sciences, University of Modena and Reggio Emilia, Via G. Campi 183, 41125 Modena, Italy

${ }^{\mathrm{d}}$ Faculty of Pharmaceutical Sciences, UNESP - Univ Estadual Paulista, Araraquara, São Paulo 14801-902, Brazil

${ }^{\mathrm{e}}$ Manchester Institute of Biotechnology, School of Chemistry, University of Manchester, Manchester M1 7DN, UK

\section{A R T I C L E I N F O}

Article history:

Received 28 September 2017

Revised 14 November 2017

Accepted 18 November 2017

Available online 21 November 2017

\section{Keywords:}

Dicyclotyrosine derivatives

CYP121A1

Mycobacterium tuberculosis

Binding affinity

Molecular modeling

X-ray crystallography

\begin{abstract}
A B S T R A C T
Three series of azole piperazine derivatives that mimic dicyclotyrosine (cYY), the natural substrate of the essential Mycobacterium tuberculosis cytochrome P450 CYP121A1, were prepared and evaluated for binding affinity and inhibitory activity (MIC) against $M$. tuberculosis. Series A replaces one phenol group of cYY with a C3-imidazole moiety, series B includes a keto group on the hydrocarbon chain preceding the series A imidazole, whilst series $\mathrm{C}$ explores replacing the keto group of the piperidone ring of cYY with a $\mathrm{CH}_{2}-$ imidazole or $\mathrm{CH}_{2}$-triazole moiety to enhance binding interaction with the heme of CYP121A1. The series displayed moderate to weak type II binding affinity for CYP121A1, with the exception of series B 10a, which displayed mixed type I binding. Of the three series, series $\mathrm{C}$ imidazole derivatives showed the best, although modest, inhibitory activity against $M$. tuberculosis $(\mathbf{1 7 d} \mathrm{MIC}=12.5 \mu \mathrm{g} / \mathrm{mL}, \mathbf{1 7 a} 50 \mu \mathrm{g} / \mathrm{mL}$ ). Crystal structures were determined for CYP121A1 bound to series A compounds $\mathbf{6 a}$ and $\mathbf{6 b}$ that show the imidazole groups positioned directly above the haem iron with binding between the haem iron and imidazole nitrogen of both compounds at a distance of $2.2 \AA$. A model generated from a $1.5 \AA$ crystal structure of CYP121A1 in complex with compound 10a showed different binding modes in agreement with the heterogeneous binding observed. Although the crystal structures of $\mathbf{6 a}$ and $\mathbf{6 b}$ would indicate binding with CYP121A1, the binding assays themselves did not allow confirmation of CYP121A1 as the target.
\end{abstract}

(c) 2017 Elsevier Ltd. All rights reserved.

\section{Introduction}

Tuberculosis (TB) is an infectious, communicable bacterial disease, most commonly of the respiratory tract, usually caused by Mycobacterium tuberculosis (Mtb). ${ }^{1}$ Despite the $47 \%$ mortality rate reduction (1990-2014), case numbers are rising in developing countries with 1.8 million deaths from TB in $2015 .^{2}$ An estimated 480,000 people developed multi-drug resistant TB (MDR-TB) in $2015 .^{2}$ The rise in MDR-TB, a form of TB caused by bacteria that do not respond to isoniazid and rifampicin, ${ }^{3}$ the two most effective

\footnotetext{
* Corresponding author at: School of Pharmacy and Pharmaceutical Sciences, Cardiff University, Redwood Building, King Edward VII Avenue, Cardiff CF10 3NB, Wales, UK.

E-mail address: simonsc@cardiff.ac.uk (C. Simons).
}

first-line TB drugs, is alarming and highlights the need for the identification of new drug targets.

A potential new target is the cytochrome P450 enzyme CYP121A1 that was shown to be essential for mycobacterial growth through gene deletion and complementation studies. ${ }^{4}$ The natural substrate of CYP121A1 is the cyclic dipeptide (CDP) dicyclotyrosine (cYY) and it was found that CYP121A1 exhibits a novel diketopiperazine modifying activity, catalysing the formation of a $\mathrm{C}-\mathrm{C}$ bond between the two tyrosyl side chains of $\mathrm{CYY}$ resulting in a novel chemical entity called mycocyclosin (Fig. 1). The role of the secondary metabolite mycocylosin in M. tuberculosis remains unclear, although CDPs and their derivatives have important biological effects, including (i) cFP in the bacterial pathogen Vibrio cholerae, production of which inhibits production of bacterial virulence factors, (ii) cLY which can inhibit biofilm formation in the 

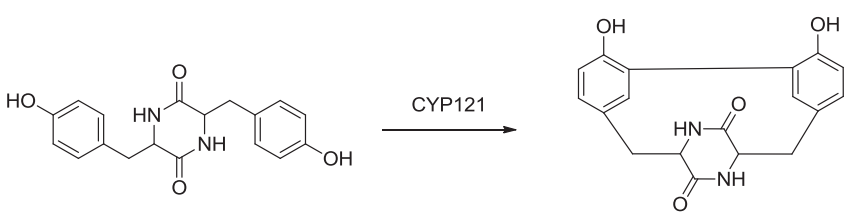

Fig. 1. Formation of mycocyclosin. M. tuberculosis CYP121A1 catalyses the oxidative crosslinking of the aryl side chains of the cyclic dipeptide, cyclo-L-Tyr-L-Tyr (cYY), to produce the novel secondary metabolite mycocyclosin.

skin bacterium Staphylococcus epidermidis; and cHP which has reported neuroprotective effects in mammals. ${ }^{5-7}$

Recent studies revealed that only cyclodipeptides with a diketopiperazine ring and two aryl side chains with L-configuration bound well to CYP121A1, and that only CYY itself was efficiently transformed to a product. ${ }^{8,9}$

The binding of $\mathrm{CYY}$ to CYP121A1 includes a direct hydrogen bond interaction between the carbonyl of $\mathrm{CYY}$ and the side chain nitrogen of Asn85, and a water-mediated hydrogen bonding pattern. Hydrophobic interactions are demonstrated on the other side chain (Fig. 2). The CDP CYY is a small molecule that partially occupies ( $300 \AA$ ) the large active site cavity $\left(1350 \AA^{3}\right)$ of CYP121A1, and makes several interactions with P450 amino acids, both directly and via interstitial active site water molecules. ${ }^{9}$

Three small series that mimic the natural substrate cYY have been developed (Fig. 3). Series A replaces one of the phenol rings of $\mathrm{CYY}$, which is positioned directly above the heme group in the crystal structure (Fig. 2), for a C3-imidazole. Flexible alignment showed that the three carbon chain allowed optimal overlap of the imidazole ring with the phenol ring (Fig. 3). Also in this series, the central piperazine ring retains the planar conformation of $\mathrm{cYY}$.

Series B includes a keto group on the hydrocarbon chain preceding the series A imidazole. The rationale for this modification of series B was to mimic the piperazine keto group, and the shorter two carbon chain, attached to a piperidine ring with more conformational flexibility, that was a sufficient length to allow overlap of the imidazole with the phenol ring (Fig. 3). Series 3 is perhaps the closest mimic retaining two aromatic rings, although it has the piperazine ring with more conformational flexibility, as with series B. In Series $\mathrm{C}$ the keto group of the piperidone ring of CYY is replaced by a $\mathrm{CH}_{2}$-imidazole or $\mathrm{CH}_{2}$-triazole, to determine whether a direct interaction between the inhibitor compound and the heme group might place the inhibitor more optimally within the active site.

The choice of imidazole and triazole as the haem-binding heterocycles was based on previous binding studies, ${ }^{10,11}$ which showed that the imidazole interacts optimally through a $\mathrm{N}$ :-Fe ${ }^{\text {III }}$-haem coordinate link, through the N3 of imidazole, while introducing an additional nitrogen in the heterocyclic ring (triazole) reduces the coordination potential through the $\mathrm{N}$ : due to the electron withdrawing effect of the additional electronegative nitrogen. This effect is further increased with two additional nitrogens (tetrazole) drawing electron density from both sides of the coordinating nitrogen. Although the triazole is expected to have a lower binding affinity for the haem iron, the lower basicity of the triazole can confer greater isoform-specific selectivity in various CYP enzymes. $^{12}$

\section{Results and discussion}

\subsection{Chemistry}

Series A began with the preparation of the 4-(substituted)-3oxo-piperazine-1-carboxylic acid tert-butyl esters (3) according to the literature procedure ${ }^{13}$ by addition of the substituted benzyl chlorides (1) to a solution of 1-Boc-3-oxopiperazine (2) in anhydrous DMF in the presence of $\mathrm{NaH}$ (Scheme 1). Deprotection of the Boc protecting group of (3) was achieved using $4 \mathrm{M} \mathrm{HCl}$

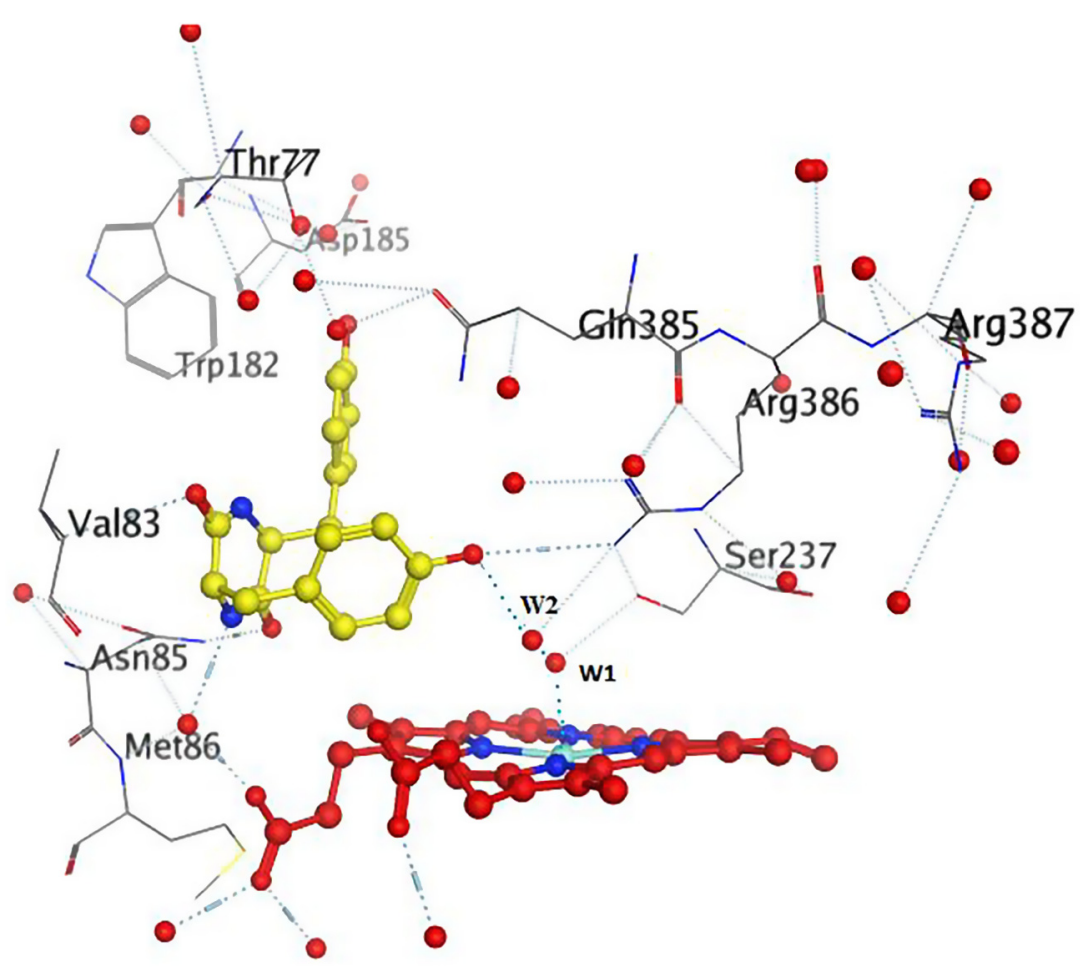

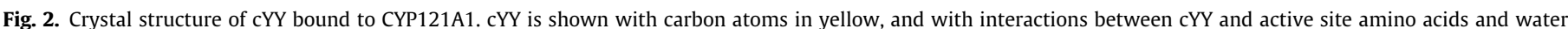

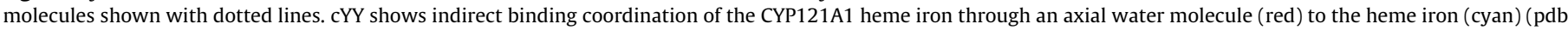
code: $3 \mathrm{G} 5 \mathrm{H})$. (For interpretation of the references to colour in this figure legend, the reader is referred to the web version of this article.) 


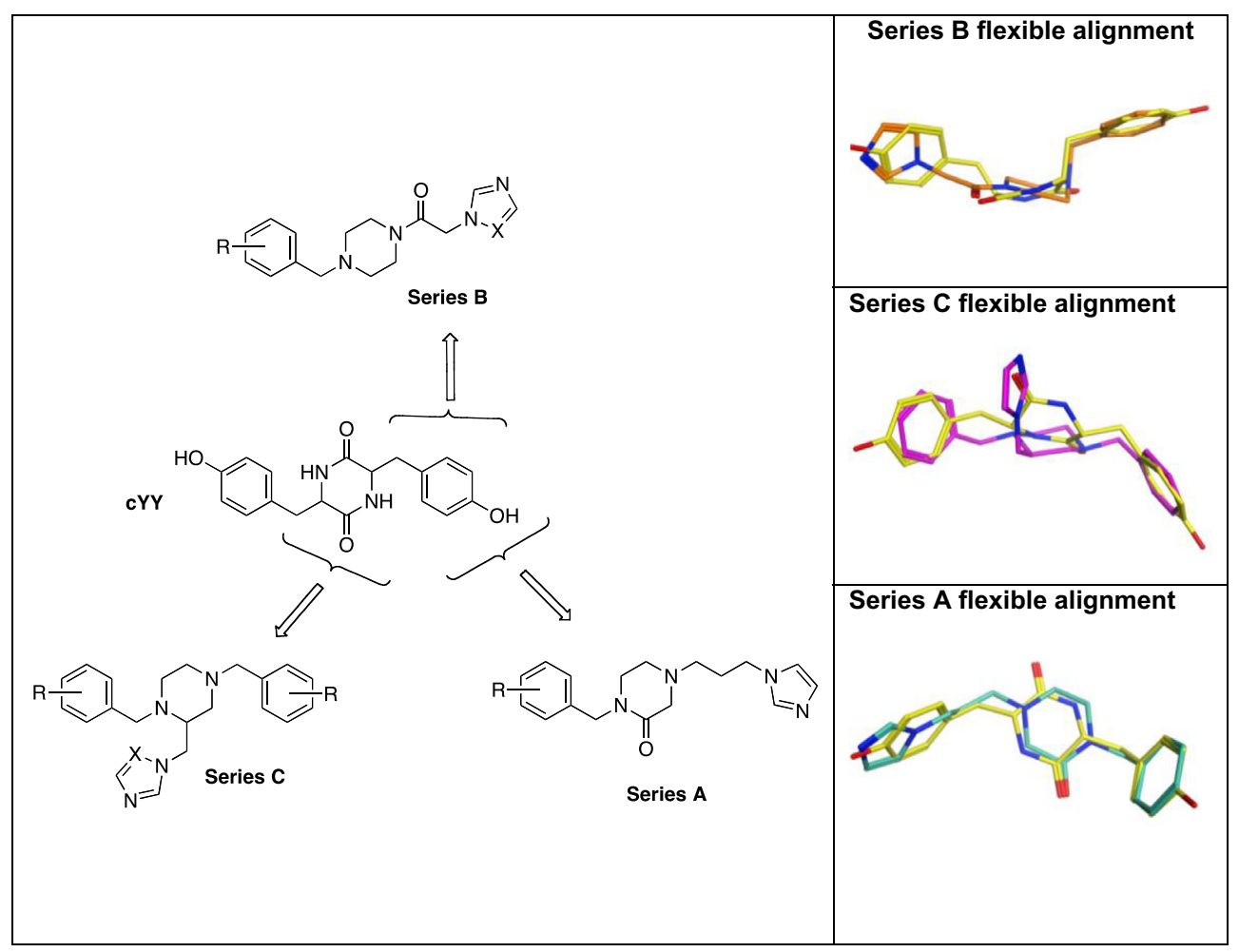

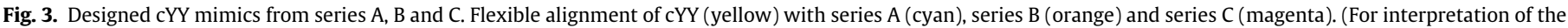
references to colour in this figure legend, the reader is referred to the web version of this article.)

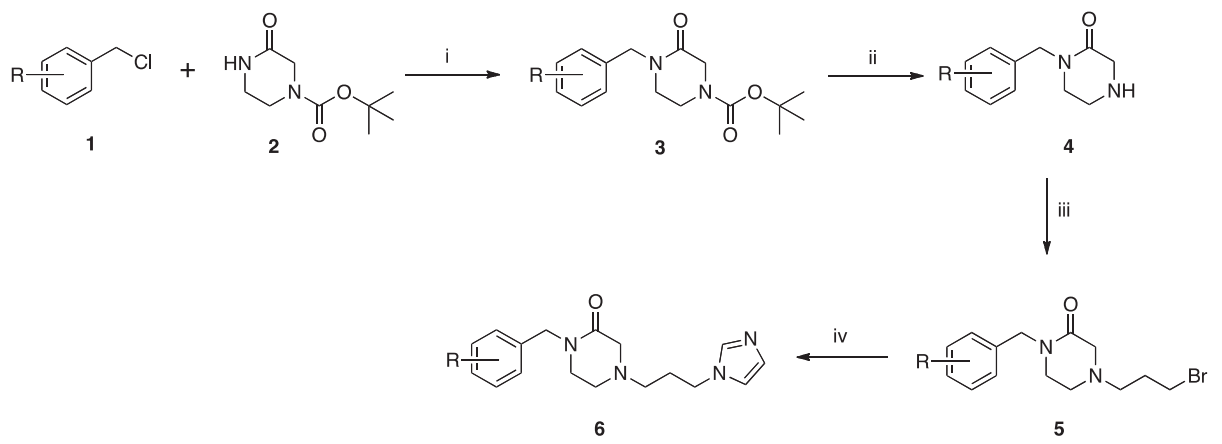

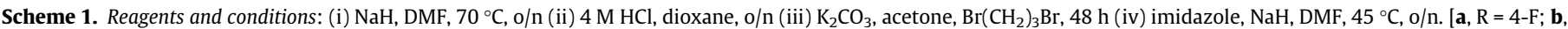
$\left.\mathrm{R}=4-\mathrm{Cl} ; \mathbf{c}, \mathrm{R}=4-\mathrm{OCH}_{3} ; \mathbf{d}, \mathrm{R}=2,4-\mathrm{diCl}\right]$.

solution in dioxane to obtain the piperazine (4) in very good yields. Treatment of 1-(substituted)-piperazin-2-one (4) with $\mathrm{K}_{2} \mathrm{CO}_{3}$ and dibromopropane for $48 \mathrm{~h}$ gave the alkylated products (5) after purification by flash column chromatography. ${ }^{14}$ Reaction of 4-(bromopropyl)-1-(4-substituted-benzyl)-piperazin-2-ones (5) with the sodium salt of imidazole gave the final imidazole products $(\mathbf{6})$ in moderate yields (Scheme 1).

Series B began with the preparation of 1-(substituted-benzyl) piperazine (8) by addition of substituted benzyl chloride (1) to a solution of excess piperazine (7) in anhydrous THF. Treatment of the formed 1-(substituted-benzyl)piperazine (8) with triethylamine and 2-chloroacetyl chloride gave the acylated products (9), ${ }^{15}$ which were pure enough to proceed for the next step. The final compounds (10) were prepared by reaction of the acylated products (9) with 1,2,4-triazole or imidazole in the presence of $\mathrm{K}_{2} \mathrm{CO}_{3}$ (Scheme 2).

For Series $C$ the substitutions were limited to unsubstituted and methoxy groups. The methoxy substituents were included as
H-bond acceptors to mimic the phenolic hydroxyl of the tyrosine group of cYY. The imines (12) were prepared by reaction of ethylenediamine and the desired benzaldehyde (11) in ethanol overnight at room temperature (Scheme 3). Subsequent reduction of the imines $(\mathbf{1 2})^{16}$ with $\mathrm{NaBH}_{4}$ gave the diamines $(\mathbf{1 3})^{17}$, which on reaction with 2,3-dibromopropionic acid ethyl ester and triethylamine in toluene at $80^{\circ} \mathrm{C}$ resulted in cyclisation to the piperazine esters (14). Ester reduction was performed using $\mathrm{LiAlH}_{4}$ giving the corresponding alcohols (15). The unsubstituted and 4methoxy derivatives 15a and 15b were then converted to the chlorides (16a and $\mathbf{1 6 b}$ ) on reaction with thionyl chloride at reflux overnight. Attempts to convert the dimethoxy alcohol $(\mathbf{1 5 c})$ to the chloride were unsuccessful with a complex reaction mixture obtained, and therefore the dimethoxy alcohol (15c) was first converted to the mesylate intermediate by reaction with methanesulphonyl chloride in the presence of base $\left(\mathrm{Et}_{3} \mathrm{~N}\right)$. Treatment of the chlorides and mesylate with either the sodium salt of imidazole or triazole generated in situ on reaction of imidazole 


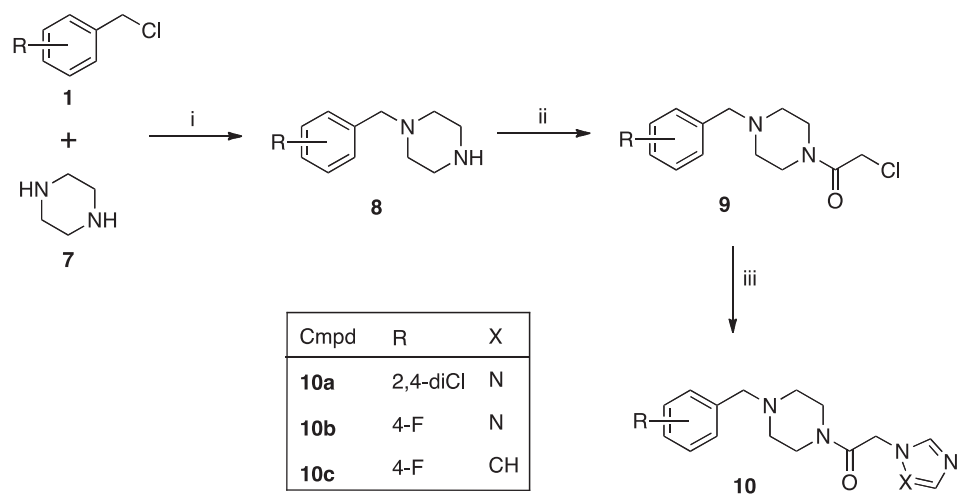

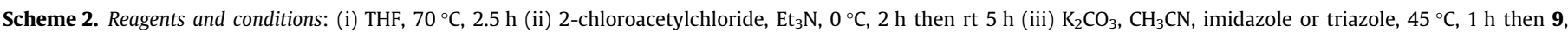
$70{ }^{\circ} \mathrm{C}, \mathrm{o} / \mathrm{n}$.

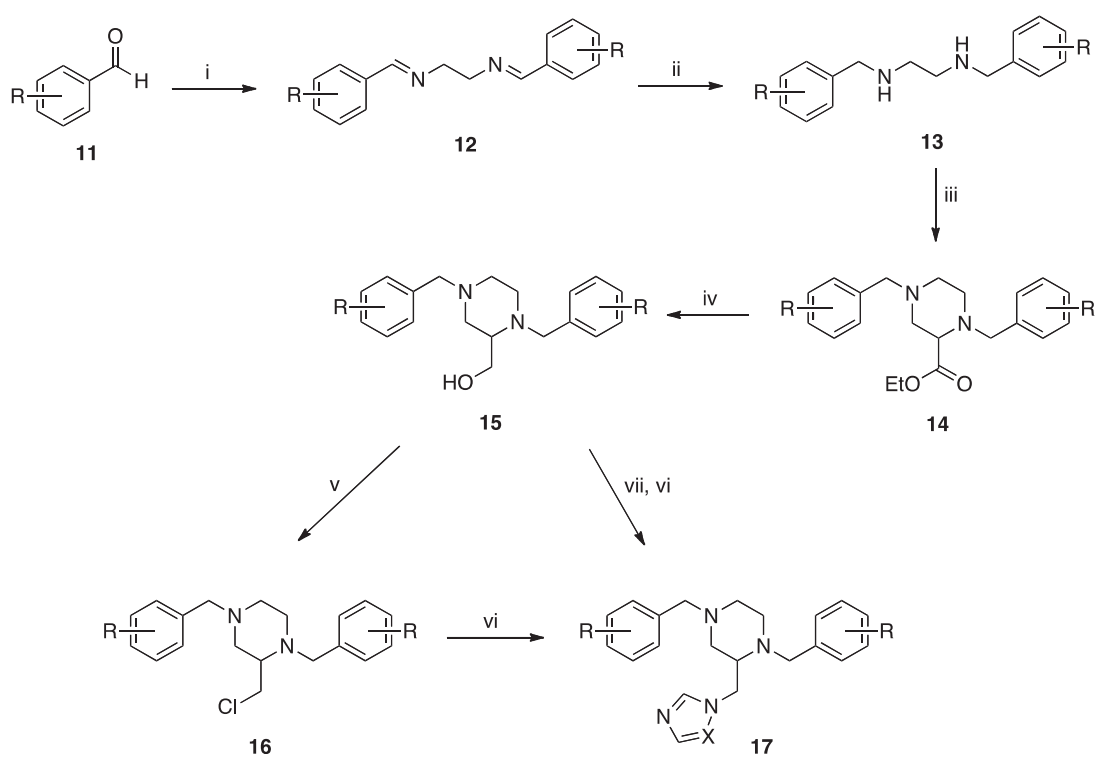

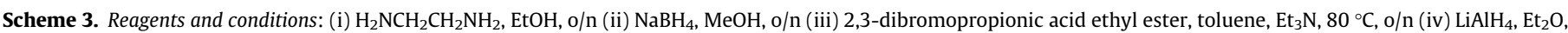

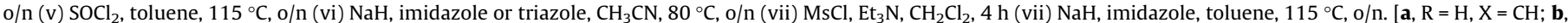
$\left.\mathrm{R}=\mathrm{H}, \mathrm{X}=\mathrm{N} ; \mathbf{c}, \mathrm{R}=4-\mathrm{OCH}_{3}, \mathrm{X}=\mathrm{N} ; \mathbf{d}, \mathrm{R}=3,5-\mathrm{diOCH}_{3}, \mathrm{X}=\mathrm{CH}\right]$.

and triazole, respectively, with $\mathrm{NaH}$ in acetonitrile or toluene, gave the final imidazole and triazole compounds (17) (Scheme 3).

\subsection{Binding affinity}

UV-visible absorption spectroscopy is an important technique for the characterization and quantification of cytochrome P450 enzymes, including the assessment of whether an applied ligand is a likely substrate or inhibitor, based on it causing a heme Soret band blue or red shift, respectively. The oxidized form of pure CYP121A1 shows spectral properties that are similar to those of many other predominantly low-spin P450 enzymes, with the major (Soret or $\gamma$ ) ferric heme band located at $416 \mathrm{~nm}$ (most P450s have the low-spin Soret feature at $\sim 418-419 \mathrm{~nm}$ ), and the smaller $\alpha$ and $\beta$ bands at 565 and $538 \mathrm{~nm}$, respectively. On reduction of CYP121A1 with sodium dithionite and binding of carbon monoxide at basic $\mathrm{pH}$, the Soret band shifts to $448 \mathrm{~nm}$ with a small decrease in intensity, confirming that cysteine thiolate coordination is retained in the $\mathrm{Fe}^{\mathrm{II}}$-CO state (Fig. 4 ). ${ }^{18}$

Binding titrations were carried out for compounds 6 (series A), $\mathbf{1 0}$ (series B) and $\mathbf{1 7}$ (series C). Results shown in Table 1 revealed that compounds from series $\mathrm{A}, \mathrm{B}$ and $\mathrm{C}$ produce small spectral changes and produce moderate to high dissociation constants using either a hyperbolic fit or the Hill function in cases where the data were sigmoidal in nature. Addition of all the compounds (with the exception of 10a) showed a type II (inhibitor-like) red shift in the heme Soret peak to a longer wavelength, indicating binding of the azole (or triazole) nitrogen to the heme iron (Fig. 5). Series A displays the tightest binding with lowest $K_{\mathrm{d}}$ values determined in particular for the halogenated compound $\mathbf{6 b}(4-\mathrm{Cl}$ group, $K_{\mathrm{d}}=81.3 \pm 2.9 \mu \mathrm{M}$ ) and compound 6a (4-F group, $K_{\mathrm{d}}=$ $225.8 \pm 2.6 \mu \mathrm{M})$. Interestingly, the triazole-containing 2-4dichloro derivative compound 10a displays a heterogeneity in binding mode with the development of a blue-shifted high spin type I (substrate-like) shoulder at $393 \mathrm{~nm}$ that is accompanied by the appearance of a small charge transfer species at $648 \mathrm{~nm}$, which is also associated with substrate-like binding. In contrast, the remaining Series B and C compounds display small type II inhibitor like spectral changes upon binding to CYP121A1 (Fig. 5). The binding of compounds $\mathbf{6 b}, \mathbf{6 c}$ and 10a to CYP121A1 was best fitted using the Hill function. The apparent cooperative nature of the binding of these ligands may suggest that more than one molecule of these compounds can enter the CYP121A1 active site, or e.g. that there are interactions between CYP121A1 proteins that influence 


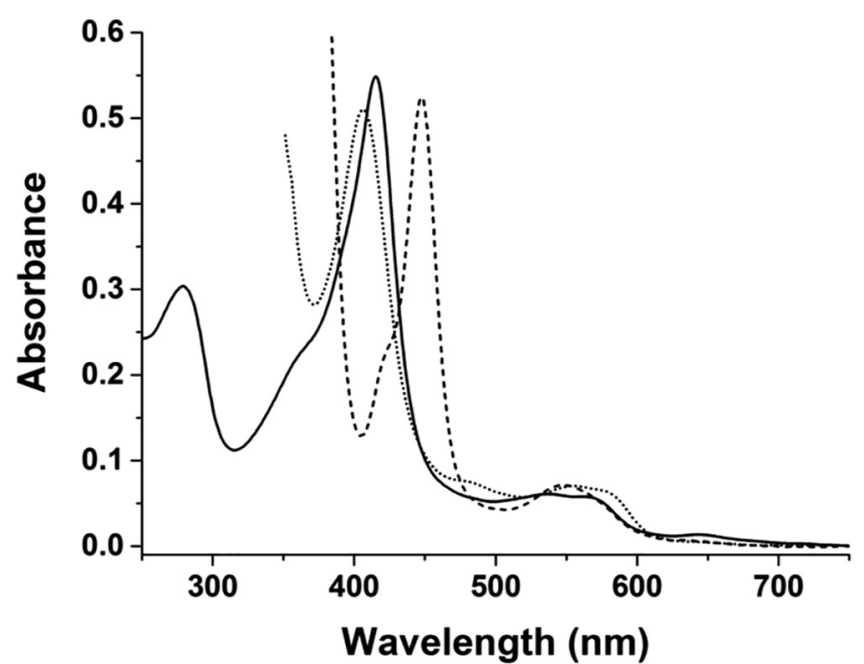

Fig. 4. Spectroscopic characteristics of CYP121A1. CYP121A1 (solid line, $5.2 \mu \mathrm{M}$ ) in the normal low-spin resting form with Soret peak at $416 \mathrm{~nm}$ and $\alpha$ and $\beta$ bands at 565 and $538 \mathrm{~nm}$, respectively. CYP121A1 retains a small degree of high-spin with a charge transfer band at $649 \mathrm{~nm}$ and small Soret shoulder at $394 \mathrm{~nm}$. Reduction with sodium dithionite (dotted line) shows a decrease in intensity of the Soret peak and shift to $406 \mathrm{~nm}$ with fusion of the $\alpha$ and $\beta$ bands to a new peak at $547 \mathrm{~nm}$. Addition of carbon monoxide to reduced CYP121A1 shows the characteristic ' $\mathrm{P} 450$ ' peak at $448 \mathrm{~nm}$.

binding affinity. Such phenomena are relatively common in P450 enzymes, as described by Korzekwa et al. ${ }^{19}$

Azole antifungal drugs (clotrimazole, econazole, fluconazole, ketoconazole and miconazole) were found to bind tightly to Mtb CYP121A1 inducing a shift of the soret peak to $423.5 \mathrm{~nm}$. The $K_{\mathrm{d}}$ values for clotrimazole, econazole and miconazole are $<0.2 \mu \mathrm{M}$ indicating tight binding. Fluconazole a triazole compound, showed weaker binding with a $K_{\mathrm{d}}$ value $8.6 \pm 0.2 \mu \mathrm{M}$, while the imidazolecontaining clotrimazole showed much higher affinity than fluconazole with a $K_{\mathrm{d}}$ value of $0.07 \pm 0.01 \mu \mathrm{M}$, as determined from a fit to the Morrison equation (Table 1 ). ${ }^{18}$ The natural substrate $\mathrm{CYY}$ has a $K_{\mathrm{d}}$ value of $5.82 \pm 0.16 \mu \mathrm{M}$.

\subsection{EPR spectroscopy of ligand binding to CYP121A1}

X-band EPR spectroscopy provides important information on P450 heme iron coordination environment and any heterogeneity therein. EPR studies were done for CYP121A1 in the ligand-free state and in complex with the compounds from series A, B and C.
Ligand-free CYP121A1 has a major rhombic LS spectrum with $\mathrm{g}$ values at $2.49\left(\mathrm{~g}_{\mathrm{z}}\right), 2.25\left(\mathrm{~g}_{\mathrm{y}}\right)$ and $1.85\left(\mathrm{~g}_{\mathrm{x}}\right)(2.49 / 2.25 / 1.85)$, consistent with a dominant axial coordination state from cysteine thiolate (proximal) and water (distal) ligands. In addition to the LS signal, there is a small proportion of HS heme retained in CYP121A1, with g-values at 7.94 and 3.59 (Table 2, Fig. 6). This small HS signal is consistent with the native CYP121A1 UV-Vis spectrum (Fig. 4). EPR analyses of CYP121A1 in complex with the compounds, with the exception of the series $\mathrm{B}$ compound 10a, revealed subtle perturbations in the EPR spectrum, with $~ 50 \%$ decreases in the HS spectral component and a slight narrowing of the LS signal with g-values of the $2.46(2.47) / 2.26 / 1.90$ (c.f. cYY $2.46,2.25,1.90)^{8}$

These results are not immediately indicative of direct coordination of the heme iron by nitrogen atoms in these molecules, although indirect ligation (via $\mathrm{H}_{2} \mathrm{O}$ molecule(s)) cannot be ruled out. In contrast, the addition of compound 10a displayed a significant perturbation of the EPR spectrum with a 9-fold increase in the amount of HS ferric heme iron (Table 2). A small degree of heterogeneity in the LS signal was also observed, with the formation of a shoulder in the LS $g_{z}$ signal at 2.41 suggesting a different binding mode for this ligand in the CYP121A1 active site. Selected EPR spectra are shown in Fig. 6.

\subsection{Antimycobacterial assay}

The derivatives of series A, B and C were screened against Mtb H37Rv by the REMA (Resazurin Microtiter Assay) method. ${ }^{20}$ In series A only compound 6d displayed inhibitory activity against $M$. tuberculosis (Table 1) and compounds from Series B were inactive (all $>100 \mu \mathrm{g} / \mathrm{mL}$ ). Series $\mathrm{C}$ was more promising with inhibitory activity observed for three of the derivatives, and with notable activity for the imidazole derivatives 17a and 17d (50 and 12.5 $\mu \mathrm{g} / \mathrm{mL}$ respectively). There would appear to be a correlation between lipophilicity (cLogP, Table 1) and antimycobacterial activity, which might be explained by enhanced uptake across the lipid dense outer mycobacterial cell wall.

\subsection{Crystallography and molecular modelling}

The structures of CYP121A1 in complex with compounds $6 \mathbf{a}$ and 6b were solved to 1.64 and $1.5 \AA$, respectively (PDB codes 504L and $504 \mathrm{~K}$ ) (Table 3 ). Compound $\mathbf{6 a}$ and $\mathbf{6 b}$ both sit in a very similar position within the CYP121A1 active site with the imidazole nitrogen coordinated to the heme iron at a distance of $2.2 \AA$ in both cases (Fig. 7). A direct $\mathrm{H}$-bond interaction between the keto group of the piperazine ring and Asn85 is observed. In addition,

Table 1

$K_{\mathrm{d}}$, MIC data and calculated $\log \mathrm{P}$ for series A and series B.

\begin{tabular}{|c|c|c|c|c|c|}
\hline Compound & $\mathrm{R}$ & $\mathrm{X}$ & $K_{\mathrm{d}}(\mu \mathrm{M})$ & MIC90 $(\mu \mathrm{g} / \mathrm{mL})$ & $\operatorname{cLog} \mathrm{P}^{\mathrm{a}}$ \\
\hline $6 \mathbf{a}$ & $4-\mathrm{F}$ & - & $225.8 \pm 2.6$ & $>100$ & 1.19 \\
\hline $6 b$ & $4-\mathrm{Cl}$ & - & $81.3 \pm 2.9$ & $>100$ & 1.59 \\
\hline $6 c$ & $4-\mathrm{OCH}_{3}$ & - & $308.9 \pm 21.8$ & $>100$ & 0.91 \\
\hline 6d & 2,4-diCl & - & $967.1 \pm 41.3$ & 100 & 2.15 \\
\hline $10 a$ & 2,4-diCl & $\mathrm{N}$ & $417 \pm 39$ & $>100$ & 1.63 \\
\hline $10 b$ & $4-\mathrm{F}$ & $\mathrm{N}$ & $960 \pm 62$ & $>100$ & 1.33 \\
\hline $10 c$ & $4-\mathrm{F}$ & $\mathrm{CH}$ & $1142 \pm 144$ & $>100$ & 1.88 \\
\hline $17 \mathbf{a}$ & $\mathrm{H}$ & $\mathrm{CH}$ & $1968 \pm 137$ & 50 & 3.56 \\
\hline $17 \mathbf{b}$ & $\mathrm{H}$ & $\mathrm{N}$ & $1834 \pm 62$ & $>100$ & 3.06 \\
\hline $17 c$ & $4-\mathrm{OCH}_{3}$ & $\mathrm{~N}$ & $1298 \pm 124$ & 100 & 2.81 \\
\hline 17d & $3,5-\mathrm{diOCH}_{3}$ & $\mathrm{CH}$ & $1435 \pm 94$ & 12.5 & 3.05 \\
\hline Fluconazole $^{15}$ & - & - & $8.6 \pm 0.2$ & $>100$ & 0.87 \\
\hline Clotrimazole $^{15}$ & - & - & $0.07 \pm 0.01$ & 0.1 & 5.97 \\
\hline $\mathrm{cYY}$ & - & - & $5.82 \pm 0.16$ & - & 1.26 \\
\hline
\end{tabular}

a Crippen's fragmentation. ${ }^{21}$ 
A
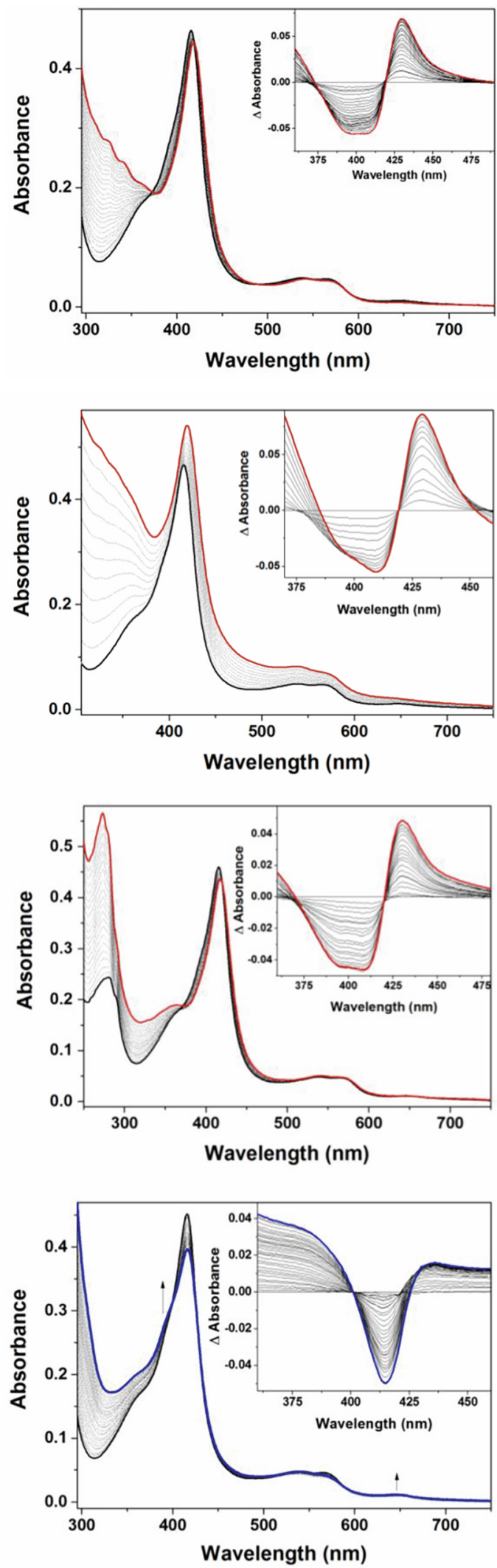

B
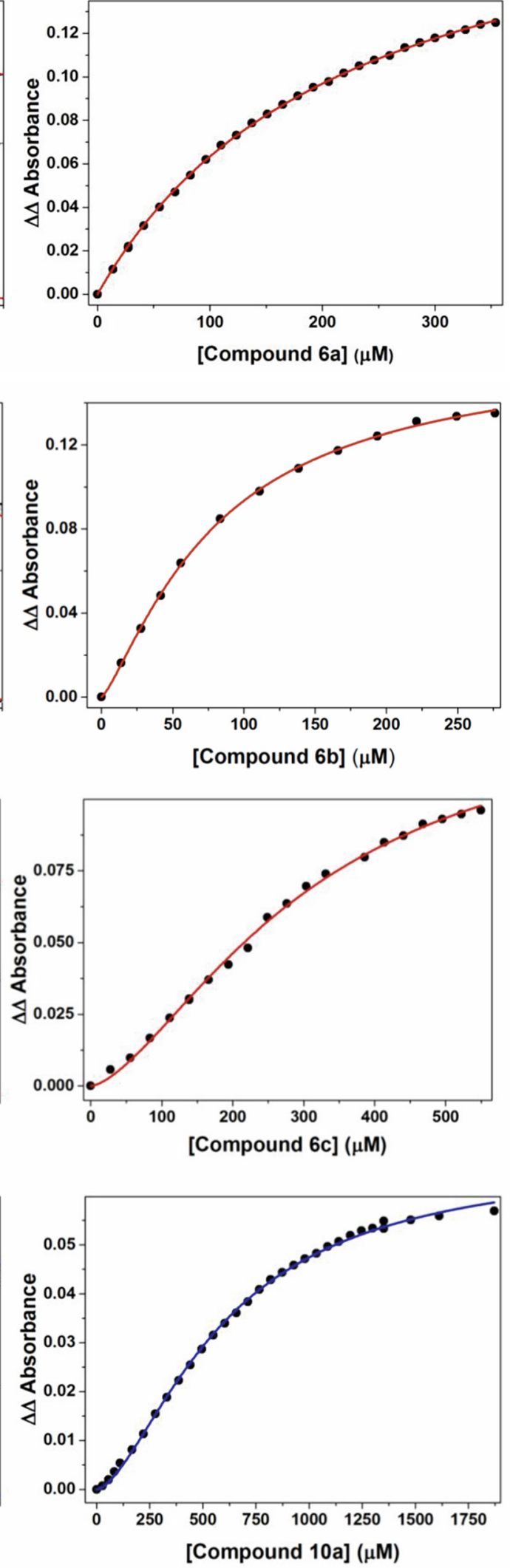

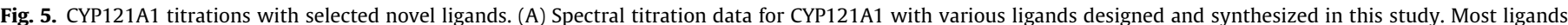

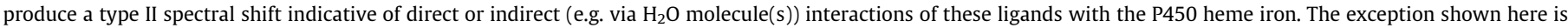

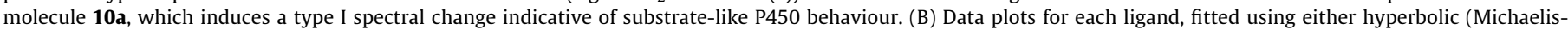

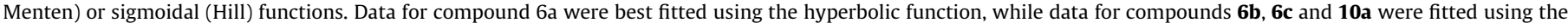
Hill function. 
Table 2

X-band EPR spectra of CYP121A1 in its ligand-free form and for complexes with ligands from series A, B and C.

\begin{tabular}{llll}
\hline $\begin{array}{l}\text { CYP121A1 } \\
\text { ligand/additive }\end{array}$ & $\begin{array}{l}\text { High-spin }(\mathrm{HS}) \\
\text { g-values }\end{array}$ & $\begin{array}{l}\text { Low-spin }(\mathrm{LS}) \\
\text { g-values }\end{array}$ & \% HS \\
\hline No additive & $7.94,3.59$ & $2.49,2.25,1.89$ & 2.5 \\
DMSO & $7.94,3.58$ & $2.49,2.25,1.89$ & 2.5 \\
$\mathbf{6 a}$ & $7.94,3.48$ & $2.46,2.26,1.90$ & 1.2 \\
$\mathbf{6 b}$ & $7.94,3.43$ & $2.46,2.26,1.90$ & 1.3 \\
$\mathbf{6 c}$ & 7.96 & $2.47,2.26,1.90$ & 1.2 \\
$\mathbf{6 d}$ & 7.97 & $2.45,2.26,1.90$ & 1.2 \\
$\mathbf{1 0 a}$ & $7.92,3.61,1.70$ & $2.47($ sh. 2.41$)$ & 22 \\
& & $2.26,1.90$ & \\
$\mathbf{1 0 b}$ & $7.96,3.51$ & $2.47,2.26,1.90$ & 1.3 \\
$\mathbf{1 0 c}$ & $7.96,3.48$ & $2.47,2.26,1.89$ & 1.2 \\
$\mathbf{1 7 a}$ & $7.95,3.58$ & $2.47,2.26,1.89$ & 1.2 \\
$\mathbf{1 7 b}$ & $7.96,3.54$ & $2.47,2.26,1.89$ & 1.3 \\
$\mathbf{1 7 c}$ & $7.95,3.52$ & $2.47,2.26,1.90$ & 1.1 \\
$\mathbf{1 7 d}$ & $7.95,3.44$ & $2.47,2.26,1.90$ & 1.1 \\
cYY & $8.05,3.44$ & $2.46,2.25,1.90$ & 2.9 \\
Fluconazole & $7.94,3.58$ & $2.45,2.26,1.90$ & 2.5 \\
\hline
\end{tabular}

The g-values for the LS and HS forms of CYP121A1 are indicated in each case with the percentage high-spin (HS) in each sample calculated from integration of the spectral peaks. The g-values are given as $g_{z} / g_{y} / g_{x}$ for both the LS and HS components. The HS $g_{x}$ signal is too weak to be resolved clearly in most samples. The low intensity of the $\mathrm{g}_{\mathrm{y}}$ signal also precludes its accurate positioning in the case of compounds $\mathbf{6 c}$ and $\mathbf{6 d}$. The "sh." in the case of compound 10a indicates a shoulder feature at $g_{z}=2.41$ on the main $g_{z}$ value at 2.47 .

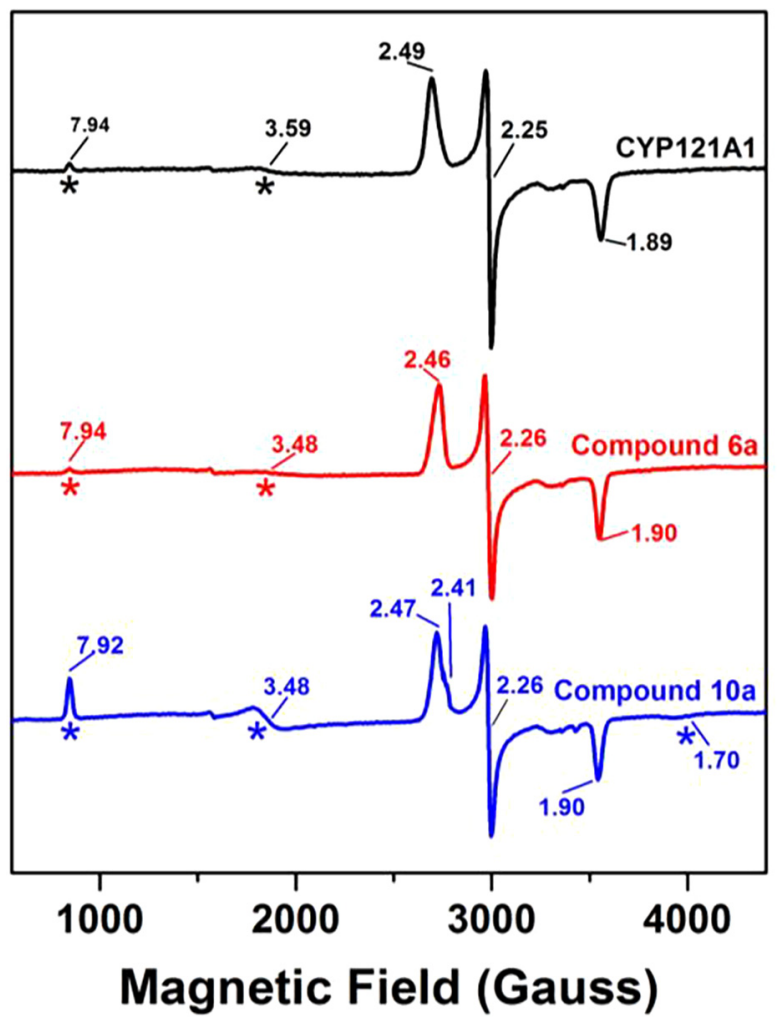

Fig. 6. X-band EPR spectra for CYP121A1 in the ligand-free form and when bound to compounds 6a and 10a. The g-values are indicated for each peak with HS signals labelled with an asterisk.

water-bridged $\mathrm{H}$-bonds are formed between the protonated piperazine amine and Met62, Val82 and Val83, and between the piperazine ring and propyl chain linker and Ala233, Gln385 and Arg386. The observed interactions of $\mathbf{6 a}$ and $\mathbf{6 b}$ closely mimic the interactions observed with cYY binding (Fig. 2).
Table 3

$\mathrm{X}$-ray crystallography data collection and final structural refinement statistics for CYP121A1 in complex with compounds $\mathbf{6 a}$ and $\mathbf{6 b}$.

\begin{tabular}{|c|c|c|}
\hline $\begin{array}{l}\text { Data Collection and } \\
\text { Refinement }^{\mathrm{a}}\end{array}$ & $\begin{array}{l}\text { CYP121A1/6a complex } \\
\text { PDB ID 504L }\end{array}$ & $\begin{array}{l}\text { CYP121A1/6b complex } \\
\text { PDB ID 504K }\end{array}$ \\
\hline \multicolumn{3}{|l|}{ Data Collection } \\
\hline Wavelength $(\AA)$ & 0.9795 & 0.9795 \\
\hline Space group & $P 6_{5} 22$ & $P 6_{5} 22$ \\
\hline \multicolumn{3}{|l|}{ Cell dimensions } \\
\hline $\mathrm{a}, \mathrm{b}, \mathrm{c}(\AA)$ & $77.53,77.53,264.95$ & $77.625,77.625,264.291$ \\
\hline$\alpha, \beta, \gamma\left({ }^{\circ}\right)$ & $90.0,90.0,120.0$ & $90.0,90.0,120.0$ \\
\hline Resolution $(\AA)$ & $65.09-1.64(1.70-1.64)$ & $47.12-1.5(1.56-1.5)$ \\
\hline Unique reflections & $58784(5714)$ & $76451(7498)$ \\
\hline Multiplicity & $19(20)$ & $19(20)$ \\
\hline Completeness (\%) & $100(100)$ & $100(100)$ \\
\hline Mean I/sigma(I) & $12.5(1.7)$ & $18.1(3.0)$ \\
\hline Wilson B-factor $\left(\AA^{2}\right)$ & 20.3 & 16.1 \\
\hline R-merge & 16.9 & 11.1 \\
\hline R-meas & 17.7 & 11.5 \\
\hline R-pim & 4.1 & 2.6 \\
\hline \multicolumn{3}{|l|}{ Refinement } \\
\hline $\mathrm{CC} 1 / 2$ & $0.99(0.49)$ & $0.99(0.91)$ \\
\hline $\begin{array}{l}\text { No. Reflections } \\
\text { (unique) }\end{array}$ & $58784(5714)$ & $76444(7497)$ \\
\hline $\begin{array}{l}\text { No. Reflections } \\
\quad \text { (R-free) }\end{array}$ & $2000(195)$ & $1993(195)$ \\
\hline R-work & $0.18(0.33)$ & $0.16(0.24)$ \\
\hline R-free & $0.20(0.34)$ & $0.19(0.26)$ \\
\hline $\begin{array}{l}\text { No. non-hydrogen } \\
\text { atoms }\end{array}$ & 3588 & 3719 \\
\hline macromolecules & 3115 & 3128 \\
\hline ligands & 71 & 81 \\
\hline solvent & 402 & 510 \\
\hline Protein residues & 394 & 394 \\
\hline RMS (bonds) & 0.016 & 0.019 \\
\hline RMS (angles) & 1.66 & 1.92 \\
\hline $\begin{array}{c}\text { Ramachandran } \\
\text { favored (\%) }\end{array}$ & 99 & 99 \\
\hline $\begin{array}{r}\text { Ramachandran } \\
\text { allowed (\%) }\end{array}$ & 0.5 & 0.98 \\
\hline $\begin{array}{c}\text { Ramachandran } \\
\text { outliers (\%) }\end{array}$ & 0 & 0 \\
\hline Rotamer outliers (\%) & 0.87 & 1.8 \\
\hline Clashscore & 3.11 & 3.24 \\
\hline Average B-factor & 23.93 & 20 \\
\hline Macromolecules & 22.66 & 18.32 \\
\hline Ligands & 25.95 & 21.99 \\
\hline Solvent & 33.39 & 30 \\
\hline No. TLS groups & 1 & 1 \\
\hline
\end{tabular}

${ }^{\text {a }}$ Data for the highest resolution shell are shown in parentheses.

A $1.5 \AA$ crystal structure of CYP121A1 in complex with compound 10a was obtained. However, incomplete ligand occupancy prevented adequate refinement of the structure. Analysis of the ligand density of compound 10a suggests that it likely acquires different binding orientations with two major conformations being rotated around the substituted piperazine central moiety of the ligand. In both orientations the imidazole groups are located pointing away from the heme towards the top of the active site cavity. In one orientation the 4-chloro group is situated 3.1 A from the heme iron and is sandwiched between the active site residues Ser237 and Ala233 (Fig. 8). In contrast, the same 4-chloro group in the second ligand orientation is $11.6 \AA$ away from the iron and rotated 35.2 degrees from the former orientation with respect to the heme iron (Fig. 8). For this second orientation, the 2-4-dichlorobenzene ring stacks with the aromatic Phe168 residue that interacts with the one of the tyrosyls of the natural substrate cYY. The different orientations of compounds $\mathbf{1 0 a}$ and the proximity of the halogen (4- $\mathrm{Cl}$ group) to the heme iron are in agreement with the UV-vis spectral data observed that reflect different binding modes and a degree of high-spin (HS) species present. 
$\mathbf{a}$
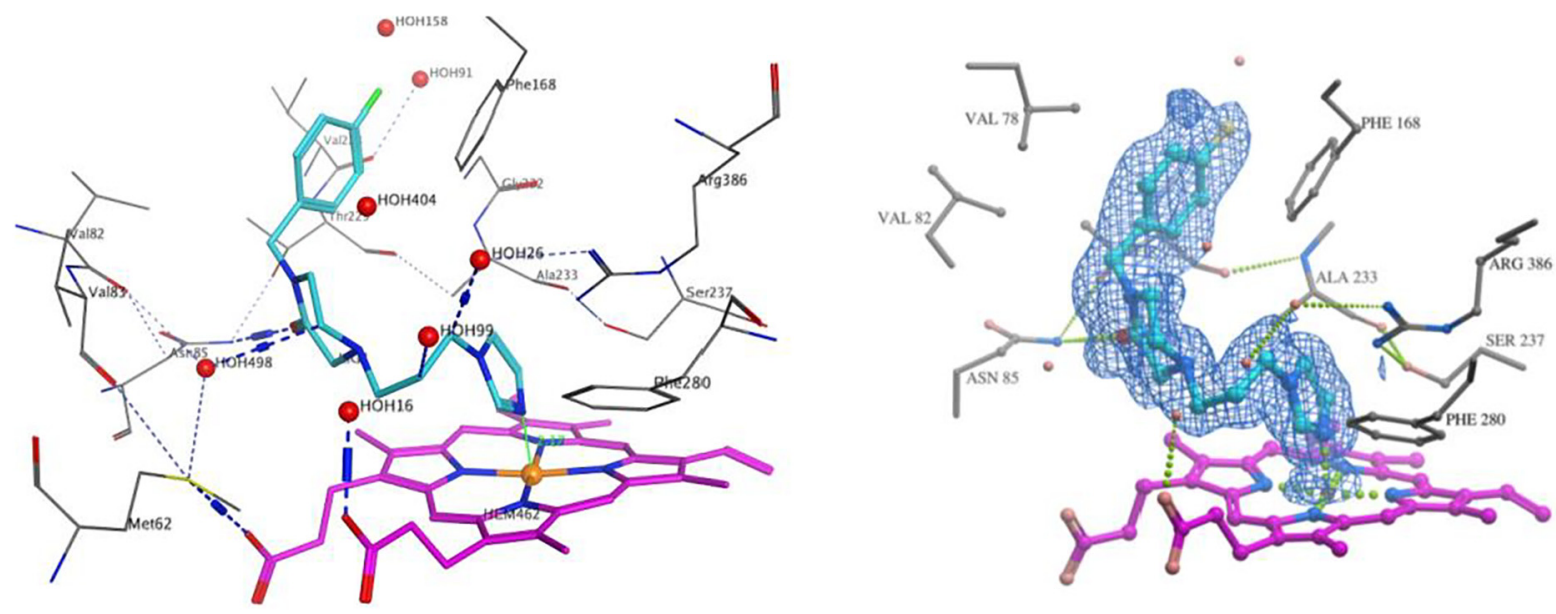

b
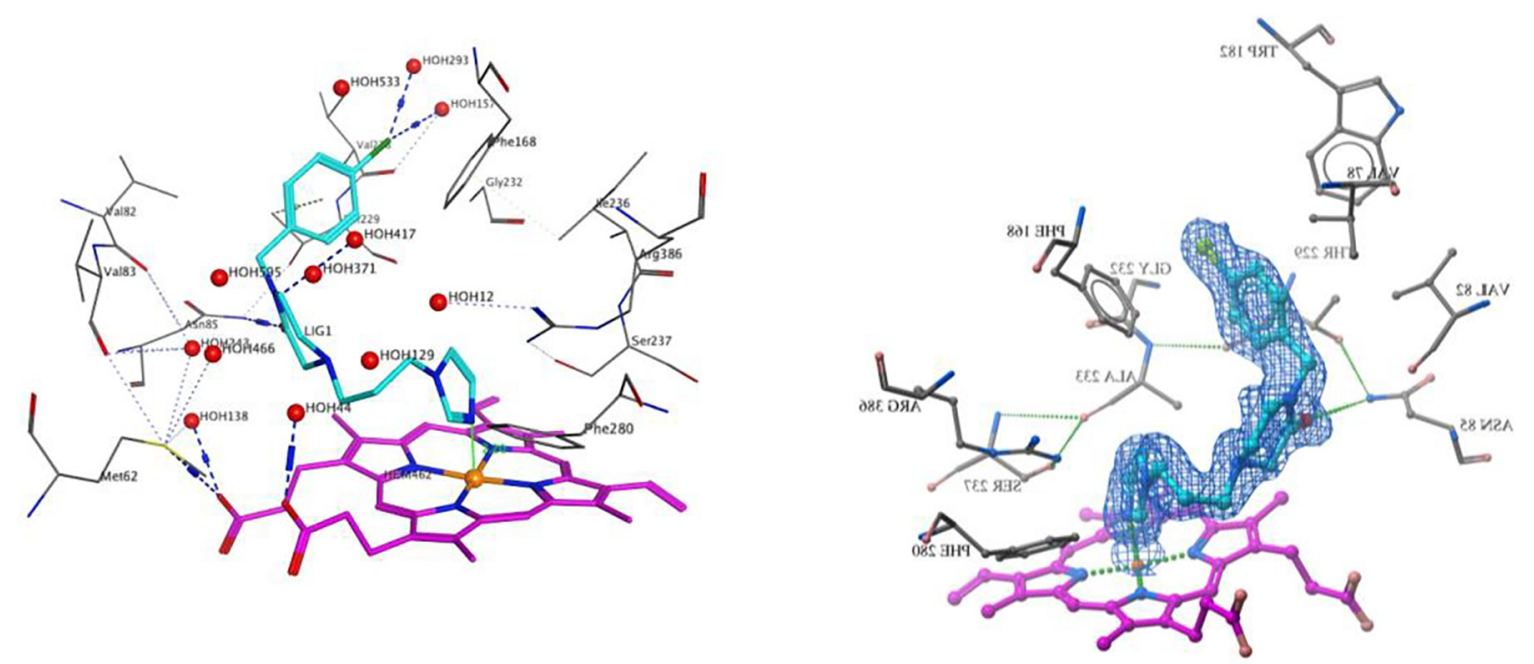

Fig. 7. X-ray crystal structures and electron density maps of (a) $6 \mathbf{a}$ and (b) $6 \mathbf{b}$ binding to CYP121A1.

Flexible alignment of series $\mathrm{C}$ with cYY as shown in Table 4 (17 (grey), natural substrate cYY (yellow)), indicated the overlap of the cYY tyrosyl groups with the two aromatic moieties. The cYY ketopiperazine ring is overlapped with the piperazine, while the imidazole and triazole rings are placed in the same position of the cYY carbonyl group, but at a longer distance where they act as hydrogen bond acceptors. The score of alignment is shown in Table 4 with compound 17c showing the best score (Table 4).

From docking studies using MOE (Molecular Operating Environment) software ${ }^{22}$ it appeared that the orientation of the Series $C$ piperazine derivatives ( $S$ - and $R$-enantiomers) in the CYP121A1 active site may allow the formation of a transition metal interaction directly between the nitrogen atom of the imidazole or triazole and the heme iron, as the distance was less than $3 \AA$. Hydrophobic interactions made by the series C compounds included those with Phe280, Ser237, Ala233, Pro285 and Thr77, which are key amino acids that interact with the natural substrate cYY (Fig. 9). However, binding studies would suggest indirect binding to the heme via a water molecule might be the more likely interaction mode.

\section{Conclusions}

A series of novel ligands were developed as potential inhibitors of the Mtb P450 enzyme CYP121A1 (Fig. 3). These molecules are structural mimics of the natural cYY substrate, but to which a heme iron-coordinating imidazole or triazole group are appended in different positions on the scaffold, with other functional groups also introduced in place of the hydroxyl group(s) in cYY. For series A, crystallography would indicate a direct binding interaction with the haem iron. However, this does not translate to strong binding affinity. It could be that the structures are just locked in a 'bound' orientation that favors their structural solution, whereas in solution they are more mobile as indicated by the small spectral changes observed in the UV-Vis spectrum. In series B compound 10a showed a distinct type I binding mode (Fig. 5) further supported by a significant perturbation of the EPR spectrum with a 9-fold increase in the amount of HS ferric heme iron (Table 2, Fig. 6). Further development of series $\mathrm{C}$ molecules is warranted based on their inhibitory activity against Mtb (Table 1). While CYP121A1 optical binding assays do not show significant perturbation of the heme spectrum, this may be due to the series $C$ inhibitors binding in an orientation that does not influence the heme axial coordination environment. However, at present we cannot conclude definitively that the activity against Mtb results from inhibition of CYP121A1. Binding affinity in the low $\mu \mathrm{M}$ range against CYP121A1 has been reported by Fonvielle et al. ${ }^{9}$ for $\mathrm{CYY}$ derivatives and by Hudson et al. $^{23,24}$ for small fragment heterocyclic inhibitors. However, no inhibitory activity (i.e. MIC values) against Mtb has been reported, and so it is unknown whether the binding affinity would translate to a potent MIC value. Similarly, 


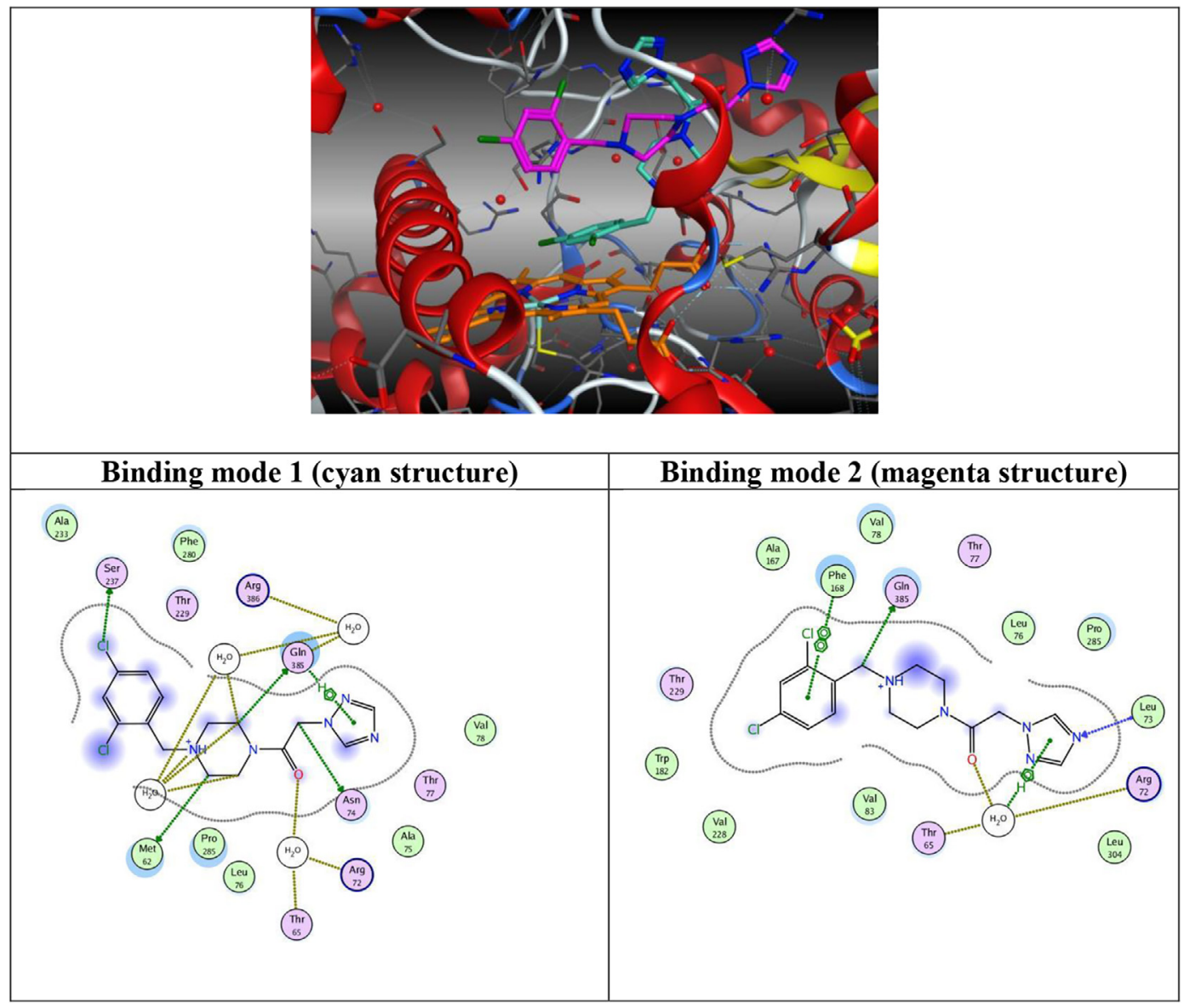

Fig. 8. Multiple binding modes for compound 10a in its complex with CYP121A1.

Table 4

Score of flexible alignment of series $C$ compounds.

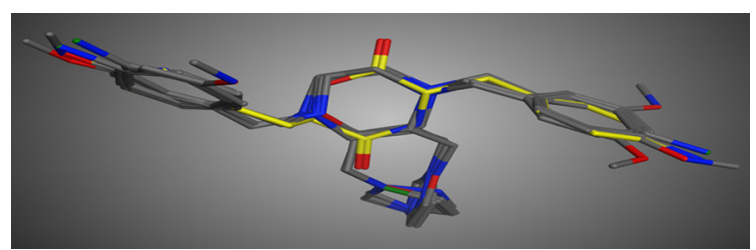<smiles>[R]c1ccc(CN2CCN(Cc3ccccc3)C(Cn3[X]cnc3)C2)cc1</smiles>

\begin{tabular}{|c|c|c|c|}
\hline Compound & $\mathrm{R}$ & $\mathrm{X}$ & Score $(\mathrm{kcal} / \mathrm{mol})$ \\
\hline $17 \mathbf{a}$ & $\mathrm{H}$ & $\mathrm{CH}$ & -21.99 \\
\hline 17b & $\mathrm{H}$ & $\mathrm{N}$ & -36.39 \\
\hline $17 c$ & $\mathrm{OCH}_{3}$ & $\mathrm{~N}$ & -38.30 \\
\hline 17d & 3,5-Dimethoxy & $\mathrm{CH}$ & -19.44 \\
\hline
\end{tabular}

the antifungal azole fluconazole shows good CYP121A1 binding affinity, but no Mtb inhibitory activity ${ }^{25}$ (although other azole drugs, e.g. econazole, do possess anti-Mtb activity). ${ }^{18}$ There are 20 different P450 isoforms encoded within the M. tuberculosis genome, ${ }^{26}$ a number of which are considered important for pathogenicity and survival in the host, and these P450s could provide novel drug targets against pathogenic mycobacteria. The synthesis of CYP121A1 inhibitors is still in its infancy and, with the exact physiological role of this enzyme still to be determined, the development of selective inhibitors will be important for the analysis of CYP121A1 mechanism, as well as being potential leads for new antibiotics that target cytochrome P450 monooxygenase chemistry in Mtb.

\section{Experimental}

\subsection{General experimental}

All chemicals, reagents and solvents were purchased from Sigma-Aldrich and Fisher Scientific companies and the required solvents were dried and stored over $4 \AA$ molecular sieves under nitrogen. Flash column chromatography was performed with silica gel 60 (Merck 40-60 nm, 230-400 mesh) and TLC was performed on precoated silica gel plates (Merck Kiesegel $60 \mathrm{~F}_{254}$ ) with visualization via UV light $(254 \mathrm{~nm})$ and/or vanillin stain. Melting points were determined on an electrothermal instrument (Gallenkamp) and are uncorrected. Compounds were visualized by irradiation 


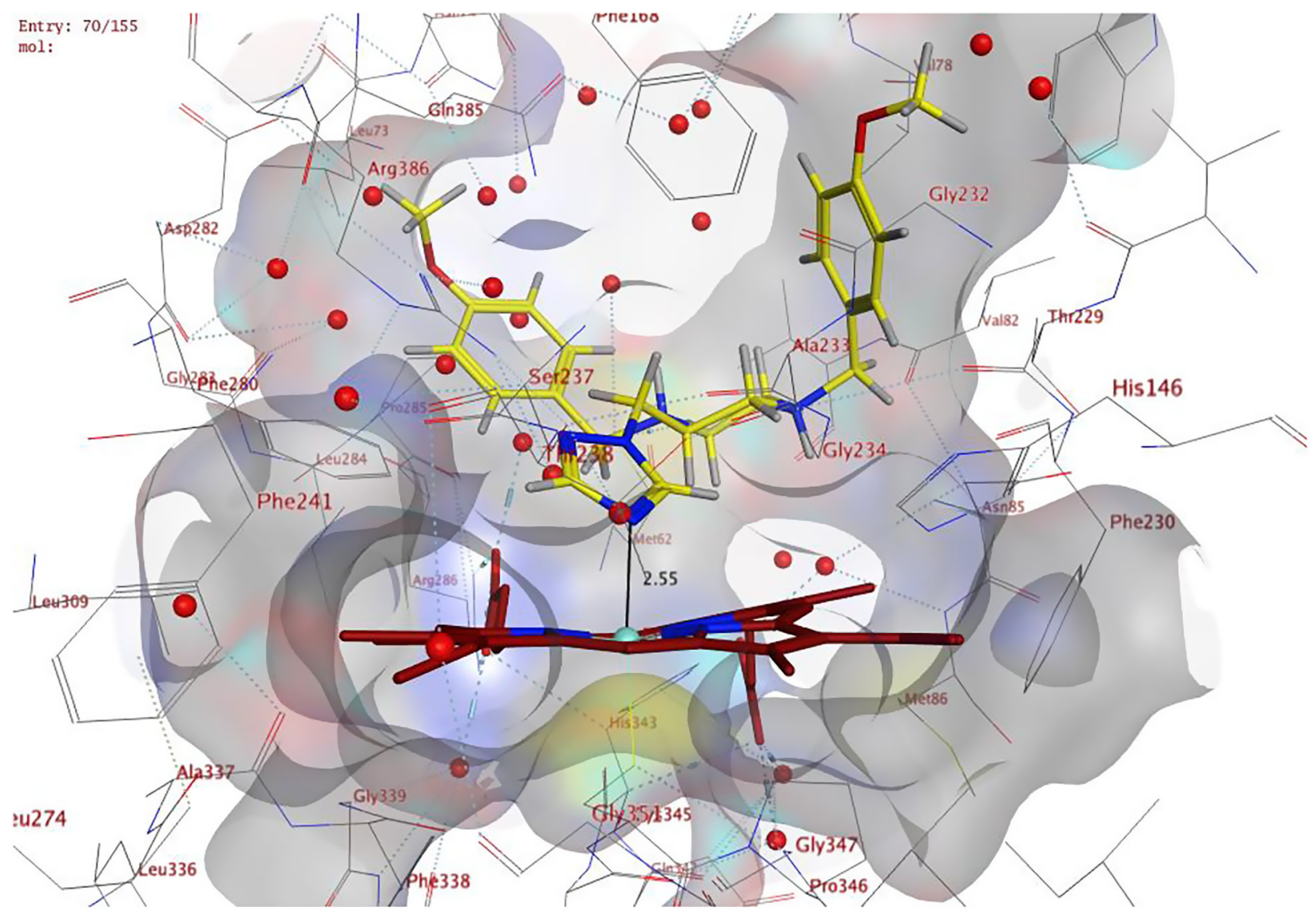

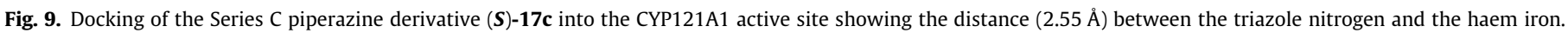

with UV light at $250 \mathrm{~nm}$ and $366 \mathrm{~nm} .{ }^{1} \mathrm{H}$ and ${ }^{13} \mathrm{C}$ NMR spectra were recorded on a Bruker Advance DPX500 spectrometer operating at $500 \mathrm{MHz}$ and $125 \mathrm{MHz}$. Mass spectra (LRMS and HRMS) were determined under EI (Electron Impact) or $\mathrm{CI}$ (Chemical Ionization) conditions at the EPSRC National Mass Spectrometry Service Centre, University of Wales, Swansea, or at the Department of Chemistry, University of Wales, Cardiff. Microanalysis data were performed by Medac Ltd., Brunel Science Centre, Surrey. The chloroacetyl derivatives (9) imines (12) and diamines (13) were prepared as previously described. ${ }^{15-17}$

\subsection{Chemistry}

\subsubsection{General method for the synthesis of 1-Boc-4-(substituted)-3-} oxopiperazine (3)

To a solution of 1-Boc-3-oxopiperazine (2) $(0.5 \mathrm{~g}, 2.49 \mathrm{mmol})$ in anhydrous DMF $(10 \mathrm{~mL})$ was added $\mathrm{NaH}(60 \%$ dispersion in mineral oil) ( $0.08 \mathrm{~g}, 3.7 \mathrm{mmol})$. The reaction was stirred at room temperature for $2 \mathrm{~h}$ then substituted benzyl chloride (1) $(2.99 \mathrm{mmol})$ was added and the reaction heated at $70{ }^{\circ} \mathrm{C}$ overnight. The reaction mixture was cooled in an ice bath, quenched with water $(5 \mathrm{~mL})$ and then evaporated under reduced pressure. The product was extracted with ethyl acetate $(100 \mathrm{~mL})$ and washed with water (3 $\times 50 \mathrm{~mL}$ ). The organic layer was dried $\left(\mathrm{MgSO}_{4}\right)$, evaporated under reduced pressure and the residue purified by flash chromatography using $\mathrm{CH}_{2} \mathrm{Cl}_{2}: \mathrm{CH}_{3} \mathrm{OH}$ gradient elution unless stated otherwise.

4.2.1.1. tert-Butyl 4-(4-fluorobenzyl)-3-oxopiperazine-1-carboxylate $(3 \boldsymbol{a})^{13}$. Synthesised using 1-chloromethyl-4-fluorobenzene $(0.43 \mathrm{~g}$, $2.9 \mathrm{mmol}$ ). Yield: $63 \%$ as a white solid, m.p: $86-92{ }^{\circ} \mathrm{C} .{ }^{1} \mathrm{H}$ NMR $\left(\mathrm{CDCl}_{3}\right): \delta 7.20(\mathrm{~m}, 2 \mathrm{H}, \mathrm{Ar}), 7.03(\mathrm{~m}, 2 \mathrm{H}, \mathrm{Ar}), 4.59\left(\mathrm{~s}, 2 \mathrm{H}, \mathrm{CH}_{2}\right)$, $4.10\left(\mathrm{~s}, 2 \mathrm{H}, \mathrm{CH}_{2}\right), 3.60\left(\mathrm{t}, J=5.5 \mathrm{~Hz}, 2 \mathrm{H}, \mathrm{CH}_{2}\right), 3.27(\mathrm{t}, J=5.5 \mathrm{~Hz}$, $\left.2 \mathrm{H}, \mathrm{CH}_{2}\right), 1.17(\mathrm{~s}, 9 \mathrm{H}, t-\mathrm{Bu}) .{ }^{13} \mathrm{C} \mathrm{NMR}\left(\mathrm{CDCl}_{3}\right): \delta 165.8(\mathrm{C}=\mathrm{O}$, piperazine), 163.4, 161.4 (C-F), $153.8(\mathrm{C}=\mathrm{O}), 132.1(\mathrm{C}), 132.05(2 \times \mathrm{CH}$, $\mathrm{Ar}), 115.7(2 \times \mathrm{CH}, \mathrm{Ar}), 80.9(\mathrm{C}, t-\mathrm{Bu}), 49.3\left(2 \times \mathrm{CH}_{2}\right), 45.6(2 \times$ $\left.\mathrm{CH}_{2}\right), 28.6\left(3 \times \mathrm{CH}_{3}, t-\mathrm{Bu}\right)$.

4.2.1.2. tert-Butyl 4-(4-chlorobenzyl)-3-oxopiperazine-1-carboxylate (3b). Synthesised according to the general procedure using 4chlorobenzylchloride $(0.48 \mathrm{~g}, 2.9 \mathrm{mmol})$ the residue was purified by flash chromatography using petroleum ether: EtOAc, the product was collected at $40: 60 \mathrm{v} / \mathrm{v}$. Yield: $41 \%$ as a white solid, m.p: $80-82{ }^{\circ} \mathrm{C} .{ }^{1} \mathrm{H}$ NMR $\left(\mathrm{CDCl}_{3}\right): \delta 7.32(\mathrm{~d}, J=8.4 \mathrm{~Hz}, 2 \mathrm{H}, \mathrm{Ar}), 7.22(\mathrm{~d}, J$ $=8.4 \mathrm{~Hz}, 2 \mathrm{H}, \mathrm{Ar}), 4.59\left(\mathrm{~s}, 2 \mathrm{H}, \mathrm{CH}_{2}\right), 4.16\left(\mathrm{~s}, 2 \mathrm{H}, \mathrm{CH}_{2}\right), 3.60(\mathrm{t}, J=$ $\left.5.4 \mathrm{~Hz}, 2 \mathrm{H}, \mathrm{CH}_{2}\right), 3.26\left(\mathrm{t}, J=5.2 \mathrm{~Hz}, 2 \mathrm{H}, \mathrm{CH}_{2}\right), 1.48(\mathrm{~s}, 9 \mathrm{H}, t-\mathrm{Bu})$. ${ }^{13} \mathrm{C}$ NMR $\left(\mathrm{CDCl}_{3}\right): \delta 164.8(\mathrm{C}=\mathrm{O}$, piperazine), $153.8(\mathrm{C}=\mathrm{O}), 134.8$ (C), $133.7(\mathrm{C}), 129.6(2 \times \mathrm{CH}, \mathrm{Ar}), 129.0(2 \times \mathrm{CH}), 80.9(\mathrm{C}, t-\mathrm{Bu})$, $49.5\left(2 \times \mathrm{CH}_{2}\right), 45.7\left(2 \times \mathrm{CH}_{2}\right), 28.3\left(3 \times \mathrm{CH}_{3}, t-\mathrm{Bu}\right)$. Anal. Calcd for $\mathrm{C}_{16} \mathrm{H}_{21} \mathrm{ClN}_{2} \mathrm{O}_{3}$ (324.80): C, 59.17; $\mathrm{H}, 6.52 ; \mathrm{N}, 8.62$. Found: $\mathrm{C}$, $59.15 ; \mathrm{H}, 6.43 ; \mathrm{N}, 8.38$.

4.2.1.3. tert-Butyl 4-(4-methoxybenzyl)-3-oxopiperazine-1-carboxylate (3c). Synthesised using 4-methoxybenzylchloride (0.46 g, 2.9 mmol). Yield: $74 \%$ as a white solid, m.p: $96-98{ }^{\circ} \mathrm{C} .{ }^{1} \mathrm{H}$ NMR $\left(\mathrm{CDCl}_{3}\right)$ : $\delta 7.2(\mathrm{~d}, J=8.6 \mathrm{~Hz}, 2 \mathrm{H}, \mathrm{Ar}), 6.87(\mathrm{~d}, J=8.5 \mathrm{~Hz}, 2 \mathrm{H}, \mathrm{Ar}), 4.56(\mathrm{~s}, 2 \mathrm{H}$, $\left.\mathrm{CH}_{2}\right), 4.14\left(\mathrm{~s}, 2 \mathrm{H}, \mathrm{CH}_{2}\right), 3.8\left(\mathrm{~s}, 3 \mathrm{H}, \mathrm{CH}_{3}\right), 3.57(\mathrm{t}, J=5.4 \mathrm{~Hz}, 2 \mathrm{H}$, $\left.\mathrm{CH}_{2}\right), 3.24\left(\mathrm{t}, J=5.4 \mathrm{~Hz}, 2 \mathrm{H}, \mathrm{CH}_{2}\right), 1.40(\mathrm{~s}, 9 \mathrm{H}, t-\mathrm{Bu}) .{ }^{13} \mathrm{C} \mathrm{NMR}$ $\left(\mathrm{CDCl}_{3}\right): \delta 165.6(\mathrm{C}=\mathrm{O}$, piperazine $), 162.5(\mathrm{C}), 153.8(\mathrm{C}=\mathrm{O}), 129.7$ $(2 \times \mathrm{CH}, \mathrm{Ar}), 128.6(\mathrm{C}), 114.1(2 \times \mathrm{CH}, \mathrm{Ar}), 80.7(\mathrm{C}, t-\mathrm{Bu}), 55.3$ $\left(\mathrm{CH}_{3}\right), 49.3\left(2 \times \mathrm{CH}_{2}\right), 45.3(2 \times \mathrm{CH}), 28.3\left(3 \times \mathrm{CH}_{3}, t-\mathrm{Bu}\right)$. Anal. Calcd for $\mathrm{C}_{17} \mathrm{H}_{24} \mathrm{~N}_{2} \mathrm{O}_{4}$ (320.38): C, 63.73; H, 7.55; N, 8.70. Found: C, 63.48; H, 7.60; N, 8.60. 
4.2.1.4. tert-Butyl-4-(2,4-dichlorobenzyl)-3-oxopiperazine-1-carboxylate (3d). Synthesised according to the general procedure using 2,4-dichloro-1-(chloromethyl)benzene ( $0.58 \mathrm{~g}, 2.9 \mathrm{mmol})$, the residue was purified by flash chromatography using petroleum ether: EtOAc, the product was collected at $40: 60 \mathrm{v} / \mathrm{v}$. Yield: $85 \%$ as a cream solid, m.p: $98-106{ }^{\circ} \mathrm{C} .{ }^{1} \mathrm{H}$ NMR $\left(\mathrm{CDCl}_{3}\right): \delta 7.42(\mathrm{~d}, J=1.7$ $\mathrm{Hz}, 1 \mathrm{H}, \mathrm{Ar}), 7.26$ (m, 2H, Ar), $4.75\left(\mathrm{~s}, 2 \mathrm{H}, \mathrm{CH}_{2}\right), 4.15\left(\mathrm{~s}, 2 \mathrm{H}, \mathrm{CH}_{2}\right)$, $3.64\left(\mathrm{t}, J=5.4 \mathrm{~Hz}, 2 \mathrm{H}, \mathrm{CH}_{2}\right), 3.33\left(\mathrm{t}, J=5.4 \mathrm{~Hz}, 2 \mathrm{H}, \mathrm{CH}_{2}\right), 1.49(\mathrm{~s}$, $9 \mathrm{H}, t-\mathrm{Bu}) \cdot{ }^{13} \mathrm{C}$ NMR $\left(\mathrm{CDCl}_{3}\right): \delta 166.1(\mathrm{C}=\mathrm{O}$, piperazine), 153.8 $(\mathrm{C}=\mathrm{O}), 134.4(\mathrm{C}), 134.2(\mathrm{C}), 132.4(\mathrm{C}), 130.7(\mathrm{CH}, \mathrm{Ar}), 129.5(\mathrm{CH}$, $\mathrm{Ar}), 127.66(\mathrm{CH}, \mathrm{Ar}), 81.0(\mathrm{C}, t-\mathrm{Bu}), 46.3\left(2 \times \mathrm{CH}_{2}\right), 46.9\left(2 \times \mathrm{CH}_{2}\right)$, $28.3(3 \mathrm{x} \mathrm{CH}, t-\mathrm{Bu})$. Anal. Calcd for $\mathrm{C}_{16} \mathrm{H}_{20} \mathrm{Cl}_{2} \mathrm{~N}_{2} \mathrm{O}_{3}$ (359.25): C, 53.49; H, 5.61; N, 7.99. Found: C, 53.62; H, 5.59; N, 7.70.

\subsubsection{General method for the synthesis of 1-(substituted)-piperazin-2- ones (4)}

To the $N$-Boc-protected amine (3) (2 mmol) was added to a $\mathrm{HCl}$ solution (4M in dioxane, $33 \mathrm{~mL}$ ). The reaction was stirred overnight at room temperature then $4 \mathrm{M}$ aqueous $\mathrm{NaOH}$ was added until alkaline. The solution was extracted with ethyl acetate $(4 \times 50$ $\mathrm{mL})$ then the organic layers combined, dried $\left(\mathrm{MgSO}_{4}\right)$ and evaporated under reduced pressure. The product was pure enough for use in the next step.

4.2.2.1. 1-(4-Fluorobenzyl)-piperazin-2-one (4a). Synthesised according to the general procedure using tert-butyl 4-(4-fluorobenzyl)-3-oxopiperazine-1-carboxylate 3a $(0.47 \mathrm{~g}, 1.52 \mathrm{mmol})$. Yield: $74 \%$ as a pale yellow oil. ${ }^{1} \mathrm{H}$ NMR $\left(\mathrm{CDCl}_{3}\right): \delta 7.21(\mathrm{~m}, 2 \mathrm{H}$, $\mathrm{Ar}), 7.02(\mathrm{~m}, 2 \mathrm{H}, \mathrm{Ar}), 4.57\left(\mathrm{~s}, 2 \mathrm{H}, \mathrm{CH}_{2}\right), 3.50\left(\mathrm{~s}, 2 \mathrm{H}, \mathrm{CH}_{2}\right), 3.22(\mathrm{t}$, $J=5.5 \mathrm{~Hz}, 2 \mathrm{H}, \mathrm{CH}_{2}$ ), 3.04 (t. $J=5.5 \mathrm{~Hz}, 2 \mathrm{H}, \mathrm{CH}_{2}$ ), 1.92 (br.s, $1 \mathrm{H}$, $\mathrm{NH}) .{ }^{13} \mathrm{C} \mathrm{NMR}\left(\mathrm{CDCl}_{3}\right): \delta 167.8(\mathrm{C}=\mathrm{O}), 163.3(\mathrm{C}-\mathrm{F}), 161.3(\mathrm{C}-\mathrm{F})$, 132.5 (C), $129.9(2 \times \mathrm{CH}, \mathrm{Ar}), 115.6(2 \times \mathrm{CH}, \mathrm{Ar}), 50.3\left(\mathrm{CH}_{2}\right), 49.2$ $\left(\mathrm{CH}_{2}\right), 47.2\left(\mathrm{CH}_{2}\right), 43.2\left(\mathrm{CH}_{2}\right)$.

4.2.2.2. 1-(4-Chlorobenzyl)-piperazin-2-one (4b). Synthesised according to the general procedure using 4-(4-chlorobenzyl)-3oxo-piperazine-1-carboxylic acid tert-butyl ester $3 \mathbf{b}(0.33 \mathrm{~g}, 1.02$ mmol). Yield: $74 \%$ as a pale yellow solid, m.p: $49-50{ }^{\circ} \mathrm{C} .{ }^{1} \mathrm{H}$ NMR $\left(\mathrm{CDCl}_{3}\right): \delta 7.29(\mathrm{~d}, J=6.9 \mathrm{~Hz}, 2 \mathrm{H}, \mathrm{Ar}), 7.20(\mathrm{~d}, J=7.1 \mathrm{~Hz}, 2 \mathrm{H}, \mathrm{Ar})$, $4.56\left(\mathrm{~s}, 2 \mathrm{H}, \mathrm{CH}_{2}\right), 3.58\left(\mathrm{~s}, 2 \mathrm{H}, \mathrm{CH}_{2}\right), 3.21\left(\mathrm{t}, J=5.2 \mathrm{~Hz}, 2 \mathrm{H}, \mathrm{CH}_{2}\right)$, 3.03 (t, J = 5.2, $\left.2 \mathrm{H}, \mathrm{CH}_{2}\right), 1.97$ (br.s, $\left.1 \mathrm{H}, \mathrm{NH}\right) .{ }^{13} \mathrm{C} \mathrm{NMR}\left(\mathrm{CDCl}_{3}\right): \delta$ 167.9 (C=0), 135.2 (C), 133.4 (C), $129.6(2 \times \mathrm{CH}, \mathrm{Ar}), 128.8(2 \times$ $\mathrm{CH}, \mathrm{Ar}), 50.3\left(\mathrm{CH}_{2}\right), 49.3\left(\mathrm{CH}_{2}\right), 47.3\left(\mathrm{CH}_{2}\right), 43.2\left(\mathrm{CH}_{2}\right)$.

4.2.2.3. 1-(4-Methoxybenzyl)-piperazin-2-one (4c). Synthesised according to the general procedure using 4-(4-methoxybenzyl)3-oxo-piperazine-1-carboxylic acid tert-butyl ester 3c $(0.46 \mathrm{~g}$, $2.08 \mathrm{mmol})$. Yield: $70 \%$ as yellow crystals, m.p: $60-64{ }^{\circ} \mathrm{C} .{ }^{1} \mathrm{H}$ $\operatorname{NMR}\left(\mathrm{CDCl}_{3}\right): \delta 7.20(\mathrm{~d}, J=8.7 \mathrm{~Hz}, 2 \mathrm{H}, \mathrm{Ar}), 6.86(\mathrm{~d}, J=8.7 \mathrm{~Hz}, 2 \mathrm{H}$, $\mathrm{Ar}), 4.54\left(\mathrm{~s}, 2 \mathrm{H}, \mathrm{CH}_{2}\right), 3.80\left(\mathrm{~s}, 3 \mathrm{H}, \mathrm{CH}_{3}\right), 3.58\left(\mathrm{~s}, 2 \mathrm{H}, \mathrm{CH}_{2}\right), 3.20(\mathrm{t}$, $\left.J=5.5 \mathrm{~Hz}, 2 \mathrm{H}, \mathrm{CH}_{2}\right), 3.02\left(\mathrm{t}, J=5.5 \mathrm{~Hz}, 2 \mathrm{H}, \mathrm{CH}_{2}\right), 1.85(\mathrm{~s}, 1 \mathrm{H}, \mathrm{NH})$. ${ }^{13} \mathrm{C}$ NMR $\left(\mathrm{CDCl}_{3}\right): \delta 167.7(\mathrm{C}=\mathrm{O}), 159.1(\mathrm{C}), 129.6(2 \times \mathrm{CH}, \mathrm{Ar})$, $129.4(\mathrm{C}), 114.0(2 \times \mathrm{CH}, \mathrm{Ar}), 55.3\left(\mathrm{CH}_{3}\right), 50.4\left(\mathrm{CH}_{2}\right), 49.2\left(\mathrm{CH}_{2}\right)$, $47.0\left(\mathrm{CH}_{2}\right), 43.2\left(\mathrm{CH}_{2}\right)$.

4.2.2.4. 1-(2,4-Dichlorobenzyl)-piperazin-2-one (4d). Synthesised according to the general procedure using 4-(2,4-dichlorobenzyl)3-oxo-piperazine-1-carboxylic acid tert-butyl ester 3d (0.76 g, $2.1 \mathrm{mmol}$ ). Yield: $72 \%$ as an orange coloured solid, m.p: 96-102 ${ }^{\circ} \mathrm{C} .{ }^{1} \mathrm{H}$ NMR $\left(\mathrm{CDCl}_{3}\right): \delta 7.39(\mathrm{~d}, J=1.95 \mathrm{~Hz}, 1 \mathrm{H}, \mathrm{Ar}), 7.25(\mathrm{~m}, 2 \mathrm{H}$, $\mathrm{Ar}), 4.71\left(\mathrm{~s}, 2 \mathrm{H}, \mathrm{CH}_{2}\right), 3.57\left(\mathrm{~s}, 2 \mathrm{H}, \mathrm{CH}_{2}\right), 3.27(\mathrm{t}, J=5.5 \mathrm{~Hz}, 2 \mathrm{H}$, $\left.\mathrm{CH}_{2}\right), 3.08\left(\mathrm{t}, J=5.2 \mathrm{~Hz}, 2 \mathrm{H}, \mathrm{CH}_{2}\right) .{ }^{13} \mathrm{C}$ NMR $\left(\mathrm{CDCl}_{3}\right): \delta 168.1$ $(\mathrm{C}=0), 134.4(\mathrm{C}), 133.9(\mathrm{C}), 132.8(\mathrm{C}), 130.4(\mathrm{CH}, \mathrm{Ar}), 129.3(\mathrm{CH}$, Ar), 127.5 (CH. Ar), $50.3\left(\mathrm{CH}_{2}\right), 47.9\left(\mathrm{CH}_{2}\right), 46.7\left(\mathrm{CH}_{2}\right), 43.2\left(\mathrm{CH}_{2}\right)$.
4.2.3. General methods for synthesis of 4-(bromopropyl)-1-(4substituted-benzyl)-piperazin-2-one (5)

Method 1: To a solution of 1-(4-substituted-benzyl)-piperazin2-one 4 (1 eq) in anhydrous acetone $(10 \mathrm{~mL} / 1.5 \mathrm{mmol})$ were added $\mathrm{K}_{2} \mathrm{CO}_{3}$ (3 eq) and dibromopropane (4 eq). The reaction mixture was stirred at room temperature for 4 days. The reaction mixture was filtered and the filtrate was evaporated. The formed residue was extract with $\mathrm{CH}_{2} \mathrm{Cl}_{2}(100 \mathrm{~mL})$ and washed with water $(50 \mathrm{~mL})$. The organic layer was dried $\left(\mathrm{MgSO}_{4}\right)$, evaporated under reduced pressure and purified by flash chromatography using $\mathrm{CH}_{2} \mathrm{Cl}_{2}: \mathrm{CH}_{3}-$ $\mathrm{OH}$ gradient elution.

Method 2: To a cooled $\left(0^{\circ} \mathrm{C}\right)$ solution of 1-(4-substituted-benzyl)-piperazin-2-one 4 (1 eq) in anhydrous acetone $(10 \mathrm{~mL} / 1.5$ $\mathrm{mmol}$ ) was added LiHMDS (1.2 eq) and the reaction stirred at 0 ${ }^{\circ} \mathrm{C}$ for $1 \mathrm{~h}$. Dibromopropane ( $2 \mathrm{eq}$ ) was added to the mixture and the reaction stirred at room temperature for $48 \mathrm{~h}$. The solvent was evaporated and the residue extracted with $\mathrm{CH}_{2} \mathrm{Cl}_{2}(100 \mathrm{~mL})$, washed with $2 \mathrm{M}$ aqueous $\mathrm{NaHCO}_{3}(50 \mathrm{~mL})$ and water $(50 \mathrm{~mL})$. The organic layer was dried $\left(\mathrm{MgSO}_{4}\right)$, evaporated under reduced pressure and purified by flash chromatography using $\mathrm{CH}_{2} \mathrm{Cl}_{2}$ : $\mathrm{CH}_{3} \mathrm{OH}$ gradient elution.

\subsubsection{4-(3-Bromopropyl)-1-(4-fluorobenzyl)-piperazin-2-one (5a).}

Synthesised according to method 2 using 1-(4-fluorobenzyl)piperazin-2-one $4 a(0.21 \mathrm{~g}, 1.05 \mathrm{mmol})$. Yield: $75 \%$ as an orange liquid. ${ }^{1} \mathrm{H}$ NMR $\left(\mathrm{CDCl}_{3}\right): \delta 7.24(\mathrm{~m}, 2 \mathrm{H}, \mathrm{Ar}), 7.00(\mathrm{~m}, 2 \mathrm{H}, \mathrm{Ar}), 4.55$ $\left(\mathrm{s}, 2 \mathrm{H}, \mathrm{CH}_{2}\right), 3.46\left(\mathrm{t}, J=6.4 \mathrm{~Hz}, 2 \mathrm{H}, \mathrm{CH}_{2}\right), 3.22(\mathrm{t}, J=5.9 \mathrm{~Hz}, 2 \mathrm{H}$, $\left.\mathrm{CH}_{2}\right), 3.21\left(\mathrm{~s}, 2 \mathrm{H}, \mathrm{CH}_{2}\right), 2.65\left(\mathrm{t}, J=5.4 \mathrm{~Hz}, 2 \mathrm{H}, \mathrm{CH}_{2}\right), 2.54(\mathrm{t}, J=6.8$ $\left.\mathrm{Hz}, 2 \mathrm{H}, \mathrm{CH}_{2}\right), 2.01\left(\mathrm{~m}, 2 \mathrm{H}, \mathrm{CH}_{2}\right) .{ }^{13} \mathrm{C} \mathrm{NMR}\left(\mathrm{CDCl}_{3}\right): \delta 167.0(\mathrm{C}=\mathrm{O})$, 163.2, 132.3 (C-F), 129.9 (2 $\times$ CH-Ar) $119.0(\mathrm{C}), 115.4(\mathrm{CH}, \mathrm{Ar})$, $115.4(\mathrm{CH}, \mathrm{Ar}), 57.3\left(\mathrm{CH}_{2}\right), 55.3\left(\mathrm{CH}_{2}\right), 49.9\left(\mathrm{CH}_{2}\right), 49.1\left(\mathrm{CH}_{2}\right), 45.9$ $\left(\mathrm{CH}_{2}\right), \quad 31.2\left(\mathrm{CH}_{2}\right), 29.7\left(\mathrm{CH}_{2}\right)$. [ES-HRMS] calculated for $\mathrm{C}_{14} \mathrm{H}_{18} \mathrm{BrFN}_{2} \mathrm{O}$ : $330.0566[\mathrm{M}+\mathrm{H}]^{+}$. Found: $330.0566[\mathrm{M}+\mathrm{H}]^{+}$.

4.2.3.2. 4-(3-Bromopropyl)-1-(4-chlorobenzyl)-piperazin-2-one (5b).

Synthesised according to method 1 using 1-(4-chlorobenzyl)piperazin-2-one $4 \mathbf{b}(0.17 \mathrm{~g}, 0.76 \mathrm{mmol})$. Yield: $42 \%$ as a yellow oil. ${ }^{1} \mathrm{H}$ NMR $\left(\mathrm{CDCl}_{3}\right): \delta 7.29$ (d, $\left.J=8.45 \mathrm{~Hz}, 2 \mathrm{H}, \mathrm{Ar}\right), 7.20$ (d, $J=$ $8.45 \mathrm{~Hz}, 2 \mathrm{H}, \mathrm{Ar}), 4.55\left(\mathrm{~s}, 2 \mathrm{H}, \mathrm{CH}_{2}\right), 3.46\left(\mathrm{t}, J=6.5 \mathrm{~Hz}, 2 \mathrm{H}, \mathrm{CH}_{2}\right)$, $3.22\left(\mathrm{~s}, 2 \mathrm{H}, \mathrm{CH}_{2}\right), 3.21\left(\mathrm{t}, J=5.5 \mathrm{~Hz}, 2 \mathrm{H}, \mathrm{CH}_{2}\right), 2.65(\mathrm{t}, J=5.5 \mathrm{~Hz}$, $\left.2 \mathrm{H}, \mathrm{CH}_{2}\right), 2.55\left(\mathrm{t}, J=6.8 \mathrm{~Hz}, 2 \mathrm{H}, \mathrm{CH}_{2}\right), 2.01\left(\mathrm{~m}, 2 \mathrm{H}, \mathrm{CH}_{2}\right) .{ }^{13} \mathrm{C} \mathrm{NMR}$ $\left(\mathrm{CDCl}_{3}\right): \delta 166.9(\mathrm{C}=\mathrm{O}), 135.1(\mathrm{C}), 133.4(\mathrm{C}), 128.8(2 \times \mathrm{CH}, \mathrm{Ar})$, $129.6(2 \times \mathrm{CH}, \mathrm{Ar}), 57.3\left(\mathrm{CH}_{2}\right), 55.3\left(\mathrm{CH}_{2}\right), 49.9\left(\mathrm{CH}_{2}\right), 48.8\left(\mathrm{CH}_{2}\right)$, $46.0\left(\mathrm{CH}_{2}\right), 31.2\left(\mathrm{CH}_{2}\right), 29.7\left(\mathrm{CH}_{2}\right)$. [ES-HRMS] calculated for $\mathrm{C}_{14} \mathrm{H}_{18} \mathrm{BrClN}_{2} \mathrm{O}$ : $344.0291[\mathrm{M}]^{+}$. Found: $344.0283[\mathrm{M}]^{+}$.

4.2.3.3. 4-(3-Bromopropyl)-1-(4-methoxybenzyl)-piperazin-2-one (5c). Synthesised according to method 1 using 1-(4-methoxybenzyl)-piperazin-2-one $4 \mathrm{c}(0.37 \mathrm{~g}, 1.67 \mathrm{mmol})$. The residue was purified by flash chromatography with EtOAc: $\mathrm{CH}_{3} \mathrm{OH}$ : gradient elution. Yield: $69 \%$ as a colourless oil. ${ }^{1} \mathrm{H}$ NMR $\left(\mathrm{CDCl}_{3}\right): \delta 7.20(\mathrm{~d}, J=8.7 \mathrm{~Hz}$, $2 \mathrm{H}, \mathrm{Ar}), 6.87(\mathrm{~d}, \mathrm{~J}=8.7 \mathrm{~Hz}, 2 \mathrm{H}, \mathrm{Ar}), 4.54\left(\mathrm{~s}, 2 \mathrm{H}, \mathrm{CH}_{2}\right), 3.81(\mathrm{~s}, 3 \mathrm{H}$, $\left.\mathrm{OCH}_{3}\right), 3.81\left(\mathrm{~s}, 2 \mathrm{H}, \mathrm{CH}_{2}\right), 3.23\left(\mathrm{~m}, 4 \mathrm{H}, 2 \times \mathrm{CH}_{2}\right), 2.66(\mathrm{t}, J=5.5 \mathrm{~Hz}$, $\left.2 \mathrm{H}, \mathrm{CH}_{2}\right), 2.56\left(\mathrm{t}, J=6.8 \mathrm{~Hz}, 2 \mathrm{H}, \mathrm{CH}_{2}\right), 2.03(\mathrm{dt}, J=6.6,13.2 \mathrm{~Hz}, 2 \mathrm{H}$, $\left.\mathrm{CH}_{2}\right) .{ }^{13} \mathrm{C}$ NMR $\left(\mathrm{CDCl}_{3}\right): \delta 166.6(\mathrm{C}=\mathrm{O}), 159.1(\mathrm{C}), 129.6(2 \times \mathrm{CH}$, $\mathrm{Ar}), 128.6(\mathrm{C}), 114.1(2 \times \mathrm{CH}, \mathrm{Ar}), 57.3\left(\mathrm{CH}_{2}\right), 55.4\left(\mathrm{CH}_{2}\right), 55.3$ $\left(\mathrm{OCH}_{3}\right), 50.0\left(\mathrm{CH}_{2}\right), 48.9\left(\mathrm{CH}_{2}\right), 45.6\left(\mathrm{CH}_{2}\right), 31.2\left(\mathrm{CH}_{2}\right), 29.7\left(\mathrm{CH}_{2}\right)$. [ES-HRMS] calculated for $\mathrm{C}_{15} \mathrm{H}_{21} \mathrm{BrN}_{2} \mathrm{O}_{2}$ : 340.0786 [M] $]^{+}$. Found: $340.0786[\mathrm{M}]^{+}$.

4.2.3.4. 4-(3-Bromopropyl)-1-(2,4-dichlorobenzyl)-piperazin-2-one (5d). Synthesised according to method 1 using 1-(2,4-dichlorobenzyl)-piperazin-2-one $4 d(0.27 \mathrm{~g}, 1.04 \mathrm{mmol})$. Yield: $61 \%$ as a yellow viscous oil. ${ }^{1} \mathrm{H} \mathrm{NMR}\left(\mathrm{CDCl}_{3}\right): \delta 7.41(\mathrm{t}, J=1.1 \mathrm{~Hz}, 1 \mathrm{H}, \mathrm{Ar}), 7.25(\mathrm{~m}$, $2 \mathrm{H}, \mathrm{Ar}), 4.71\left(\mathrm{~s}, 2 \mathrm{H}, \mathrm{CH}_{2}\right), 3.49\left(\mathrm{t}, J=6.5 \mathrm{~Hz}, 2 \mathrm{H}, \mathrm{CH}_{2}\right), 3.30(\mathrm{t}, J=$ $\left.5.5 \mathrm{~Hz}, 2 \mathrm{H}, \mathrm{CH}_{2}\right), 3.25\left(\mathrm{~s}, 2 \mathrm{H}, \mathrm{CH}_{2}\right), 2.72\left(\mathrm{t}, J=5.5 \mathrm{~Hz}, 2 \mathrm{H}, \mathrm{CH}_{2}\right)$, 
$2.59\left(\mathrm{t}, J=6.8 \mathrm{~Hz}, 2 \mathrm{H}, \mathrm{CH}_{2}\right), 2.05\left(\mathrm{dt}, J=6.6,13.3 \mathrm{~Hz}, 2 \mathrm{H}, \mathrm{CH}_{2}\right) .{ }^{13} \mathrm{C}$ $\operatorname{NMR}\left(\mathrm{CDCl}_{3}\right): \delta 167.2(\mathrm{C}=\mathrm{O}), 134.4(\mathrm{C}), 133.9(\mathrm{C}), 132.7(\mathrm{C})$, $130.4(\mathrm{CH}, \mathrm{Ar}), 129.4(\mathrm{CH}, \mathrm{Ar}), 127.6(\mathrm{CH}, \mathrm{Ar}), 57.4\left(\mathrm{CH}_{2}\right), 55.4$ $\left(\mathrm{CH}_{2}\right), 50.0\left(\mathrm{CH}_{2}\right), 46.6\left(\mathrm{CH}_{2}\right), 46.4\left(\mathrm{CH}_{2}\right), 31.1\left(\mathrm{CH}_{2}\right), 29.7\left(\mathrm{CH}_{2}\right)$.

4.2.4. General methods for synthesis of 4-(3-imidazol-1-yl-propyl)-1(substituted)-piperazin-2-one (6)

To a solution of $\mathrm{NaH}$ (2 eq) in dry DMF (10 mL/2 mmol of 5), imidazole ( $2 \mathrm{eq}$ ) was added, the reaction was stirred for $1 \mathrm{~h}$ at $30{ }^{\circ} \mathrm{C}$ then cooled to room temperature. 4-(Bromoalkyl)-1-(4-substituted-benzyl)-piperazin-2-one (5) (1 eq) was added to the reaction mixture and left stirring overnight at $45^{\circ} \mathrm{C}$. Water $(3 \mathrm{~mL})$ was added to quench excess $\mathrm{NaH}$ and the reaction was evaporated under reduced pressure. Water $(50 \mathrm{~mL})$ was added to the formed residue and the product was extracted with ethyl acetate $(3 \times$ $50 \mathrm{~mL}$ ). The organic layers were combined and washed with water $(50 \mathrm{~mL})$. The organic layer was then dried $\left(\mathrm{MgSO}_{4}\right)$, evaporated under reduced pressure and purified by preparative TLC, using EtOAc: $\mathrm{CH}_{3} \mathrm{OH}$ 5:1 v/v as eluent.

4.2.4.1. 4-(3-(1H-imidazol-1-yl)propyl)-1-(4-fluorobenzyl)piperazin2-one $(\mathbf{6 a})$. Synthesised according to the general procedure using 5a $(0.15 \mathrm{~g}, 0.45 \mathrm{mmol})$ Yield: $48 \%$ as a yellow oil. ${ }^{1} \mathrm{H} \mathrm{NMR}\left(\mathrm{CDCl}_{3}\right)$ : $\delta 7.47$ (s, 1H, imidazole), $7.24(\mathrm{~m}, 2 \mathrm{H}, \mathrm{Ar}), 7.06$ (s, 1H, imidazole), $7.02(\mathrm{~m}, 2 \mathrm{H}, \mathrm{Ar}), 6.90(\mathrm{~s}, 1 \mathrm{H}$, imidazole $), 4.5\left(\mathrm{~s}, 2 \mathrm{H}, \mathrm{CH}_{2}\right), 4.04(\mathrm{t}$, $\left.J=6.7 \mathrm{~Hz}, 2 \mathrm{H}, \mathrm{CH}_{2}\right), 3.23\left(\mathrm{t}, J=5.4 \mathrm{~Hz}, 2 \mathrm{H}, \mathrm{CH}_{2}\right), 3.19\left(\mathrm{~s}, 2 \mathrm{H}, \mathrm{CH}_{2}\right)$, $2.61\left(\mathrm{t}, J=5.4 \mathrm{~Hz}, 2 \mathrm{H}, \mathrm{CH}_{2}\right), 2.34\left(\mathrm{t}, J=6.6 \mathrm{~Hz}, 2 \mathrm{H}, \mathrm{CH}_{2}\right), 1.94(\mathrm{~m}$, $\left.2 \mathrm{H}, \mathrm{CH}_{2}\right) .{ }^{13} \mathrm{C}$ NMR $\left(\mathrm{CDCl}_{3}\right): \delta 166.7(\mathrm{C}=\mathrm{O}), 163.3(\mathrm{C}-\mathrm{F}), 161.3(\mathrm{C}-$ F), 137.3 (CH, imidazole), 132.3 (C), $129.9(2 \times \mathrm{CH}-\mathrm{Ar}), 129.5(\mathrm{CH}$, imidazole), $118.8(\mathrm{CH}$, imidazole $), 115.5(2 \times \mathrm{CH}, \mathrm{Ar}), 57.1\left(\mathrm{CH}_{2}\right)$, 53.6 $\left(\mathrm{CH}_{2}\right), 50.0\left(\mathrm{CH}_{2}\right), 48.8\left(\mathrm{CH}_{2}\right), 45.8\left(\mathrm{CH}_{2}\right), 44.2\left(\mathrm{CH}_{2}\right), 27.9$ $\left(\mathrm{CH}_{2}\right)$. [ES-HRMS] calculated for $\mathrm{C}_{17} \mathrm{H}_{21} \mathrm{FN}_{4} \mathrm{O}$ : $316.1699[\mathrm{M}+\mathrm{H}]^{+}$. Found: $316.1694[\mathrm{M}+\mathrm{H}]^{+}$.

4.2.4.2. 4-(3-(1H-imidazol-1-yl)propyl)-1-(4-chlorobenzyl)piperazin2-one (6b). Synthesised according to the general procedure using 5b $(0.11 \mathrm{~g}, 0.32 \mathrm{mmol})$. Yield: $22 \%$ as a yellow oil. ${ }^{1} \mathrm{H} \mathrm{NMR}\left(\mathrm{CDCl}_{3}\right)$ : $\delta 7.40$ (s, 1H, imidazole), 7.32 (d, J=7.5 Hz, 2H, Ar), 7.22 (d, $J=9.0$ $\mathrm{Hz}, 2 \mathrm{H}, \mathrm{Ar}$ ), 7.07 (s, 1H, imidazole), 6.91 (s, 1H, imidazole), 5.31 (s, $\left.2 \mathrm{H}, \mathrm{CH}_{2}\right), 4.58\left(\mathrm{~s}, 2 \mathrm{H}, \mathrm{CH}_{2}\right), 4.04\left(\mathrm{t}, J=7.0 \mathrm{~Hz}, 2 \mathrm{H}, \mathrm{CH}_{2}\right), 3.24(\mathrm{t}, J=$ $\left.6.0 \mathrm{~Hz}, 2 \mathrm{H}, \mathrm{CH}_{2}\right), 2.61\left(\mathrm{t}, J=5.5 \mathrm{~Hz}, 2 \mathrm{H}, \mathrm{CH}_{2}\right), 2.34(\mathrm{t}, J=7.0 \mathrm{~Hz}, 2 \mathrm{H}$, $\left.\mathrm{CH}_{2}\right), 1.94\left(\mathrm{~m}, 2 \mathrm{H}, \mathrm{CH}_{2}\right) \cdot{ }^{13} \mathrm{C} \mathrm{NMR}\left(\mathrm{CDCl}_{3}\right): \delta 166.7(\mathrm{C}=\mathrm{O}), 135.0(\mathrm{C})$, $133.5(\mathrm{C}), 129.7(2 \times \mathrm{CH}, \mathrm{Ar}), 129.6(\mathrm{CH}$, imidazole $), 129.0(\mathrm{CH}, \mathrm{imi}-$ dazole), $128.9(2 \times \mathrm{CH}, \mathrm{Ar}), 118.5(\mathrm{CH}$, imidazole $), 57.1\left(\mathrm{CH}_{2}\right), 53.6$ $\left(\mathrm{CH}_{2}\right), 50.0\left(\mathrm{CH}_{2}\right), 48.9\left(\mathrm{CH}_{2}\right), 45.9\left(\mathrm{CH}_{2}\right), 44.2\left(\mathrm{CH}_{2}\right), 27.9\left(\mathrm{CH}_{2}\right)$. [ES-HRMS] calculated for $\mathrm{C}_{17} \mathrm{H}_{21} \mathrm{ClN}_{4} \mathrm{O}: 332.1404[\mathrm{M}+\mathrm{H}]^{+}$. Found: $332.1410[\mathrm{M}+\mathrm{H}]^{+}$.

4.2.4.3. 4-(3-(1H-imidazol-1-yl)propyl)-1-(4-methoxybenzyl)piperazin-2-one $(\mathbf{6 c})$. Synthesised according to the general procedure using 5c $(0.33 \mathrm{~g}, 0.97 \mathrm{mmol})$. Yield: $57 \%$ as a yellow liquid. ${ }^{1} \mathrm{H}$ NMR (DMSO $\left.d_{6}\right): \delta 7.46(\mathrm{~s}, 1 \mathrm{H}$, imidazole), $7.20(\mathrm{~d}, J=8.7 \mathrm{~Hz}, 2 \mathrm{H}$, $\mathrm{Ar}), 7.06(\mathrm{~s}, 1 \mathrm{H}$, imidazole), $6.90(\mathrm{~s}, 1 \mathrm{H}$, imidazole $), 6.87(\mathrm{~d}, J=$ $8.7 \mathrm{~Hz}, 2 \mathrm{H}, \mathrm{Ar}), 4.54\left(\mathrm{~s}, 2 \mathrm{H}, \mathrm{CH}_{2}\right), 4.03\left(\mathrm{t}, J=6.7 \mathrm{~Hz}, 2 \mathrm{H}, \mathrm{CH}_{2}\right), 3.8$ $\left(\mathrm{s}, 3 \mathrm{H}, \mathrm{CH}_{3}\right), 3.22\left(\mathrm{t}, J=5.5 \mathrm{~Hz}, 2 \mathrm{H}, \mathrm{CH}_{2}\right), 3.18\left(\mathrm{~s}, 2 \mathrm{H}, \mathrm{CH}_{2}\right), 2.5(\mathrm{t}$, $\left.J=5.4 \mathrm{~Hz}, \mathrm{CH}_{2}\right), 2.32\left(\mathrm{t}, J=6.7 \mathrm{~Hz}, 2 \mathrm{H}, \mathrm{CH}_{2}\right), 1.93\left(\mathrm{~m}, 2 \mathrm{H}, \mathrm{CH}_{2}\right)$. ${ }^{13} \mathrm{C}$ NMR (DMSO $\left.d_{6}\right): \delta 166.6(\mathrm{C}=0), 159.0(\mathrm{C}, \mathrm{Ar}), 129.6(2 \times \mathrm{CH}$, $\mathrm{Ar}), 128.5$ (C, Ar), 118.8 (CH-imidazole), 114.1 ( $2 \times \mathrm{CH}, \mathrm{Ar}), 113.7$ ( $\mathrm{CH}$, imidazole $), 110.6(\mathrm{CH}$, imidazole $), 57.1\left(\mathrm{CH}_{2}\right), 55.3\left(\mathrm{OCH}_{3}\right)$, $53.6\left(\mathrm{CH}_{2}\right), 50.1\left(\mathrm{CH}_{2}\right), 48.9\left(\mathrm{CH}_{2}\right), 45.6\left(\mathrm{CH}_{2}\right), 44.2\left(\mathrm{CH}_{2}\right), 27.9$ $\left(\mathrm{CH}_{2}\right)$. [ES-HRMS] calculated for $\mathrm{C}_{18} \mathrm{H}_{24} \mathrm{~N}_{4} \mathrm{O}_{2}: 328.1899[\mathrm{M}+\mathrm{H}]^{+}$, Found: $328.1901[\mathrm{M}+\mathrm{H}]^{+}$.

4.2.4.4. 4-(3-(1H-imidazol-1-yl)propyl)-1-(2,4-dichlorobenzyl)piperazin-2-one $(\boldsymbol{6 d})$. Synthesised according to the general procedure using 5d (0.27 g, $0.71 \mathrm{mmol})$. Yield: $51 \%$ as a yellow viscous oil.
${ }^{1} \mathrm{H}$ NMR $\left(\mathrm{CDCl}_{3}\right): \delta 7.07$ (s, $1 \mathrm{H}$, imidazole), 7.53 (s, $1 \mathrm{H}$, imidazole), $7.40(\mathrm{~d}, J=1.2 \mathrm{~Hz}, 1 \mathrm{H}, \mathrm{Ar}), 7.25(\mathrm{~m}, 2 \mathrm{H}, \mathrm{Ar}), 6.92(\mathrm{~s}, 1 \mathrm{H}$, imidazole), $4.71\left(\mathrm{~s}, 2 \mathrm{H}, \mathrm{CH}_{2}\right), 4.06\left(\mathrm{t}, J=6.7 \mathrm{~Hz}, 2 \mathrm{H}, \mathrm{CH}_{2}\right), 3.29(\mathrm{t}, J=5.4 \mathrm{~Hz}, 2 \mathrm{H}$, $\mathrm{CH}_{2}$ ), 3.21 (br.s, $\left.2 \mathrm{H}, \mathrm{CH}_{2}\right), 2.65\left(\mathrm{t}, J=5.4 \mathrm{~Hz}, 2 \mathrm{H}, \mathrm{CH}_{2}\right), 2.36(\mathrm{t}, J=6.7$ $\left.\mathrm{Hz}, 2 \mathrm{H}, \mathrm{CH}_{2}\right), 1.96\left(\mathrm{dt}, J=6.7,13.4 \mathrm{~Hz}, 2 \mathrm{H}, \mathrm{CH}_{2}\right) .{ }^{13} \mathrm{C} \mathrm{NMR}\left(\mathrm{CDCl}_{3}\right): \delta$ $167.0(\mathrm{C}=\mathrm{O}), 137.2$ ( $\mathrm{CH}$, imidazole), $134.3(\mathrm{C}), 133.9(\mathrm{C}), 132.6(\mathrm{C})$, 130.3 ( $\mathrm{CH} \mathrm{Ar}), 129.3(\mathrm{CH}, \mathrm{Ar}), 129.0(\mathrm{CH}$, imidazole), $127.5(\mathrm{CH}, \mathrm{Ar})$, $118.9\left(\mathrm{CH}\right.$, imidazole), $57.0\left(\mathrm{CH}_{2}\right), 53.5\left(\mathrm{CH}_{2}\right), 49.9\left(\mathrm{CH}_{2}\right), 46.5$ $\left(\mathrm{CH}_{2}\right), 46.4\left(\mathrm{CH}_{2}\right), 44.3\left(\mathrm{CH}_{2}\right), 27.8\left(\mathrm{CH}_{2}\right)$. [ES-HRMS] calculated for $\mathrm{C}_{17} \mathrm{H}_{20} \mathrm{Cl}_{2} \mathrm{~N}_{4} \mathrm{O}$ : $366.1014[\mathrm{M}+\mathrm{H}]^{+}$. Found: $366.1021[\mathrm{M}+\mathrm{H}]^{+}$.

4.2.5. General method for the synthesis of 2-imidazol or triazol-1-yl-1[(substituted-benzyl)piperazin-1-yl]ethanone (10)

To a stirred suspension of potassium carbonate (4 eq) in dry $\mathrm{CH}_{3} \mathrm{CN}(10 \mathrm{~mL} / 5 \mathrm{mmol}$ of 9), imidazole or 1,2,4-triazole (4 eq) was added. The mixture was heated under reflux for $1 \mathrm{~h}$ at $45^{\circ} \mathrm{C}$ and monitored using TLC system $\mathrm{CH}_{3} \mathrm{OH}$ :EtOAc $1: 4 \mathrm{v} / \mathrm{v}$. The reaction was cooled to room temperature then the crude 1-(substituted-benzyl-piperazin-1-yl)-2-chloroethanone 9 (1eq) was added. The reaction was heated under reflux at $70^{\circ} \mathrm{C}$ overnight. The solvent was evaporated, then water $(30 \mathrm{~mL})$ was added and then extracted with $\mathrm{CH}_{2} \mathrm{Cl}_{2}(3 \times 30 \mathrm{~mL})$. The organic layer was dried $\left(\mathrm{MgSO}_{4}\right)$, evaporated under reduced pressure and purified by preparative TLC using $\mathrm{CH}_{3} \mathrm{OH}$ : EtOAc $1: 4 \mathrm{v} / \mathrm{v}$.

4.2.5.1. 1-(4-(2,4-Dichlorobenzyl)piperazin-1-yl)-2-(1H-1,2,4-triazol1-yl)ethanone (10a). Synthesised using 2-chloro-1-[4-(2,4dichlorobenzyl)-piperazin-1-yl]-ethanone (0.6 g, $1.8 \mathrm{mmol})$. Yield: $32 \%$ as a pale yellow solid, m.p: $70-74{ }^{\circ} \mathrm{C} .{ }^{1} \mathrm{H}$ NMR $\left(\mathrm{CDCl}_{3}\right): \delta 8.25$ (s, $1 \mathrm{H}$, triazole), $7.97(\mathrm{~s}, 1 \mathrm{H}$, triazole), $7.42(\mathrm{~d}, J=2.1 \mathrm{~Hz}, 1 \mathrm{H}, \mathrm{Ar})$, $7.40(\mathrm{~d}, J=2.1 \mathrm{~Hz}, 1 \mathrm{H}, \mathrm{Ar}), 7.25(\mathrm{dd}, J=2.1,8.3 \mathrm{~Hz}, 1 \mathrm{H}, \mathrm{Ar}), 5.06$ (s, 2H, $\mathrm{CH}_{2} \mathrm{CO}$ ), 3.68 (app.s, 2H, $\mathrm{CH}_{2}$-piperazine), $3.64(\mathrm{~s}, 2 \mathrm{H}$, $\mathrm{PhCH}_{2}$ ), 3.58 (app.s, $2 \mathrm{H}, \mathrm{CH}_{2}$-piperazine), 2.55 (m, $4 \mathrm{H}, 2 \times \mathrm{CH}_{2}-$ piperazine $).{ }^{13} \mathrm{C}$ NMR $\left(\mathrm{CDCl}_{3}\right): \delta 163.6(\mathrm{C}=\mathrm{O}), 151.7(\mathrm{CH}$, triazole $)$, $144.7(\mathrm{CH}$, triazole), $135.1(2 \times \mathrm{C}), 133.8(\mathrm{C}), 131.6(\mathrm{CH}, \mathrm{Ar})$, $129.4(\mathrm{CH}, \mathrm{Ar}), 127.1(\mathrm{CH}, \mathrm{Ar}), 58.4\left(\mathrm{CH}_{2}\right), 52.7\left(\mathrm{CH}_{2}\right), 52.3\left(\mathrm{CH}_{2}\right)$, $50.4\left(\mathrm{CH}_{2}\right), 45.3\left(\mathrm{CH}_{2}\right), 42.3\left(\mathrm{CH}_{2}\right)$. [APCI-HRMS] calculated for $\mathrm{C}_{15} \mathrm{H}_{17} \mathrm{C}_{12} \mathrm{~N}_{5}$ : $354.0888[\mathrm{M}+\mathrm{H}]^{+}$. Found: $354.0890[\mathrm{M}+\mathrm{H}]^{+}$.

4.2.5.2. 1-(4-(4-Fluorobenzyl)piperazin-1-yl)-2-(1H-1,2,4-triazol1-yl)ethanone (10b). Synthesised using 2-chloro-1-[4-(4-fluorobenzyl)piperazin-1-yl]ethanone $(0.2 \mathrm{~g}, 0.7 \mathrm{mmol})$. Yield: $35 \%$ as a yellow solid, m.p: $116-120{ }^{\circ} \mathrm{C} .{ }^{1} \mathrm{H}$ NMR $\left(\mathrm{CDCl}_{3}\right): \delta 8.25(\mathrm{~s}, 1 \mathrm{H}$, triazole), $7.95(\mathrm{~s}, 1 \mathrm{H}$, triazole), $7.30(\mathrm{~m}, 2 \mathrm{H}, \mathrm{Ar}), 7.02(\mathrm{~m}, 2 \mathrm{H}, \mathrm{Ar})$, $5.06\left(\mathrm{~s}, 2 \mathrm{H}, \mathrm{CH}_{2} \mathrm{CO}\right.$ ), 3.67 (t, $J=4.5 \mathrm{~Hz}, 2 \mathrm{H}, \mathrm{CH}_{2}$-piperazine), 4.56 (t, $J=4.7 \mathrm{~Hz}, 2 \mathrm{H}, \mathrm{CH}_{2}$-piperazine), $3.52\left(\mathrm{~s}, 2 \mathrm{H}, \mathrm{PhCH}_{2}\right), 2.47(\mathrm{~m}$, $4 \mathrm{H}, 2 \times \mathrm{CH}_{2}$-piperazine). ${ }^{13} \mathrm{C} \mathrm{NMR}\left(\mathrm{CDCl}_{3}\right): \delta 163.6(\mathrm{C}=\mathrm{O}), 163.2$, $161.3(\mathrm{C}-\mathrm{F}), 151.7(\mathrm{CH}$, triazole $), 144.8(\mathrm{CH}$, triazole $), 130.7(\mathrm{CH}$, $\mathrm{Ar}), 130.7(\mathrm{CH}, \mathrm{Ar}), 115.4(\mathrm{CH}, \mathrm{Ar}), 115.2(\mathrm{CH}, \mathrm{Ar}), 62.1\left(\mathrm{CH}_{2}\right)$, $52.6\left(\mathrm{CH}_{2}\right), 52.2\left(\mathrm{CH}_{2}\right), 50.4\left(\mathrm{CH}_{2}\right), 45.2\left(\mathrm{CH}_{2}\right), 42.2\left(\mathrm{CH}_{2}\right)$. [APCIHRMS calculated for $\mathrm{C}_{15} \mathrm{H}_{18} \mathrm{FN}_{5} \mathrm{O}$ : $304.1574[\mathrm{M}+\mathrm{H}]^{+}$. Found: $304.1561[\mathrm{M}+\mathrm{H}]^{+}$.

4.2.5.3. 1-(4-(4-Fluorobenzyl)piperazin-1-yl)-2-(1H-imidazol-1-yl) ethanone (10c). Synthesised using 2-chloro-1-[4-(4-fluorobenzyl)piperazin-1-yl]-ethanone $(0.2 \mathrm{~g}, 0.7 \mathrm{mmol})$. Yield: $36 \%$ as a yellow oil. ${ }^{1} \mathrm{H} \mathrm{NMR}\left(\mathrm{CDCl}_{3}\right): \delta 7.51$ (s, $1 \mathrm{H}$, imidazole), 7.28 (m, 2H, Ar), 7.08 (s, 1H, imidazole), 7.03 (m, 2H, Ar), 6.9 (s, 1H, imidazole), 4.77 (s, $2 \mathrm{H}, \mathrm{CH}_{2} \mathrm{CO}$ ), 3.64 (br.s, $2 \mathrm{H}, \mathrm{CH}_{2}$-piperazine), 3.57 (s, $2 \mathrm{H}, \mathrm{PhCH}_{2}$ ), 3.45 (br.s, $2 \mathrm{H}, \mathrm{CH}_{2}$-piperazine), 2.43 (br.s, $4 \mathrm{H}, 2 \times \mathrm{CH}_{2}$-piperazine). ${ }^{13} \mathrm{C} \mathrm{NMR}\left(\mathrm{CDCl}_{3}\right): \delta 164.5(\mathrm{C}=\mathrm{O}), 163.1,161.2(\mathrm{C}-\mathrm{F}), 138.0(\mathrm{CH}, \mathrm{imi}-$ dazole), $133.1(\mathrm{C}), 130.6(2 \times \mathrm{CH}, \mathrm{Ar}), 129.1$ ( $\mathrm{CH}$, imidazole), 120.2 ( $\mathrm{CH}$, imidazole), $115.2(\mathrm{CH}, \mathrm{Ar}), 115.1(\mathrm{CH}, \mathrm{Ar}), 61.97\left(\mathrm{CH}_{2}\right), 52.6$ $\left(\mathrm{CH}_{2}\right), 52.4\left(\mathrm{CH}_{2}\right), 48.0\left(\mathrm{CH}_{2}\right), 45.1\left(\mathrm{CH}_{2}\right), 42.3\left(\mathrm{CH}_{2}\right)$. [APCI-HRMS] calculated for $\mathrm{C}_{16} \mathrm{H}_{19} \mathrm{FN}_{4} \mathrm{O}$ : $303.1621[\mathrm{M}+\mathrm{H}]^{+}$. Found: 303.1608 $[\mathrm{M}+\mathrm{H}]^{+}$. 
4.2.6. General procedure for the synthesis of ethyl 1,4-bis(substituted benzyl)piperazine-2-carboxylate (14)

2,3-Dibromopropionic acid ethyl ester (1.04 eq) was added dropwise to a solution of diamine 13 (1 eq) in hot dry toluene at $80{ }^{\circ} \mathrm{C}(70 \mathrm{~mL} / 24 \mathrm{mmol}$ of 13$)$ and triethylamine (2.5 eq). The reaction mixture was refluxed overnight then the reaction was cooled, washed with saturated aqueous $\mathrm{NaHCO}_{3}(3 \times 25 \mathrm{~mL})$ and brine $(2$ $\times 25 \mathrm{~mL}$ ). The organic layer was dried $\left(\mathrm{MgSO}_{4}\right)$, concentrated under reduced pressure and purified by flash chromatography gradient elution with $\mathrm{CH}_{2} \mathrm{Cl}_{2}: \mathrm{CH}_{3} \mathrm{OH}$. The pure product appeared at $1-2 \%$ methanol, unless otherwise indicated.

4.2.6.1. Ethyl 1,4-dibenzylpiperazine-2-carboxylate (14a) ${ }^{27}$. Synthesised according to the general procedure using $N, N^{\prime}$-dibenzylethylendiamine $13 a(3.9 \mathrm{~g}, 16.33 \mathrm{mmol})$. Yield: $54 \%$ as a yellow oil. ${ }^{1} \mathrm{H}$ NMR $\left(\mathrm{CDCl}_{3}\right): \delta 7.33(\mathrm{~m}, 8 \mathrm{H}, \mathrm{Ar}), 7.28(\mathrm{~m}, 2 \mathrm{H}, \mathrm{Ar})$ $4.21\left(\mathrm{q}, J=3.5 \mathrm{~Hz}, 2 \mathrm{H}, \mathrm{CH}_{2} \mathrm{CH}_{3}\right), 3.96\left(\mathrm{~d}, J=13.3 \mathrm{~Hz}, 1 \mathrm{H}, \mathrm{CH}_{2} \mathrm{Ph}\right)$, $3.66\left(\mathrm{~m}, 1 \mathrm{H}, \mathrm{CH}_{2} \mathrm{Ph}\right), 3.60\left(\mathrm{~d}, J=13.2 \mathrm{~Hz}, 1 \mathrm{H}, \mathrm{CH}_{2} \mathrm{Ph}\right), 3.49(\mathrm{~d}, J=$ $\left.13.2 \mathrm{~Hz}, 1 \mathrm{H}, \mathrm{CH}_{2} \mathrm{Ph}\right), 3.37(\mathrm{~m}, 1 \mathrm{H}, \mathrm{CH}$-piperazine), $3.13(\mathrm{~m}, 1 \mathrm{H}$, piperazine), $2.86(\mathrm{~m}, 1 \mathrm{H}$, piperazine), $2.66(\mathrm{~d}, J=9.1 \mathrm{~Hz}, 1 \mathrm{H}$, piperazine), $2.5\left(\mathrm{~m}, 3 \mathrm{H}\right.$, piperazine), $1.32\left(\mathrm{t}, J=7.1 \mathrm{~Hz}, 3 \mathrm{H}, \mathrm{CH}_{2} \mathrm{CH}_{3}\right) .{ }^{13} \mathrm{C}$ $\operatorname{NMR}\left(\mathrm{CDCl}_{3}\right): \delta 172.1$ (C, C=0), 138.3 (C, Ar), 138.0 (C, Ar), 129.0 (2 $\times \mathrm{CH}, \mathrm{Ar}), 128.8(2 \times \mathrm{CH}, \mathrm{Ar}), 128.6(2 \times \mathrm{CH}, \mathrm{Ar}), 128.5(2 \times \mathrm{CH}, \mathrm{Ar})$, $127.5(2 \times \mathrm{CH}, \mathrm{Ar}), 62.8(\mathrm{CH}), 62.7\left(\mathrm{CH}_{2}\right), 60.4\left(\mathrm{CH}_{2}\right), 59.7\left(\mathrm{CH}_{2}\right)$, $55.5\left(\mathrm{CH}_{2}\right), 53.1\left(\mathrm{CH}_{2}\right), 48.6\left(\mathrm{CH}_{2}\right), 14.3\left(\mathrm{CH}_{3}\right)$.

4.2.6.2. Ethyl 1,4-bis(4-methoxybenzyl)piperazine-2-carboxylate (14b). Synthesised according to the general procedure using $N$, $N$ '-bis(4-methoxybenzyl)ethane-1,2-diamine 13b (2 g, $6.6 \mathrm{mmol})$. Yield: $73 \%$ as an orange oil. ${ }^{1} \mathrm{H}$ NMR $\left(\mathrm{CDCl}_{3}\right): \delta 7.25(\mathrm{~d}, J=9.0 \mathrm{~Hz}$, $2 \mathrm{H}, \mathrm{Ar}$ ), 7.21 (d, J=7.5 Hz, 2H, Ar), 6.85 (m, 4H, Ar), 4.19 (q, $J=$ $\left.7.1 \mathrm{~Hz}, 2 \mathrm{H}, \mathrm{CH}_{2} \mathrm{CH}_{3}\right), 3.88$ (d, $J=13.1 \mathrm{~Hz}, 1 \mathrm{H}, \mathrm{CH}_{2} \mathrm{Ph}$ ), $3.78(\mathrm{~s}, 6 \mathrm{H}$, $\left.2 \times \mathrm{OCH}_{3}\right), 3.51\left(\mathrm{~d}, J=13.0 \mathrm{~Hz}, 2 \mathrm{H}, \mathrm{CH}_{2} \mathrm{Ph}\right), 3.68(\mathrm{~d}, J=13.0 \mathrm{~Hz}$, $\left.1 \mathrm{H}, \mathrm{CH}_{2} \mathrm{Ph}\right), 3.29(\mathrm{~m}, 1 \mathrm{H}$, piperazine), $3.05(\mathrm{~m}, 1 \mathrm{H}$, piperazine), $2.69(\mathrm{~s}, 1 \mathrm{H}$, piperazine $), 2.63(\mathrm{~s}, 1 \mathrm{H}$, piperazine $), 2.48(\mathrm{~m}, 2 \mathrm{H}$, piperazine), 2.39 ( $\mathrm{m}, 1 \mathrm{H}$, piperazine), $1.26\left(\mathrm{t}, \mathrm{J}=7.1,3 \mathrm{H}, \mathrm{CH}_{2} \mathrm{CH}_{3}\right) \cdot{ }^{13} \mathrm{C}$ $\operatorname{NMR}\left(\mathrm{CDCl}_{3}\right): \delta 172.0(\mathrm{C}=\mathrm{O}), 158.8\left(\mathrm{C}, 2 \times \underline{\mathrm{C}}-\mathrm{OCH}_{3}\right), 130.5(2 \times$ $\mathrm{CH}, \mathrm{Ar}), 130.3(2 \times \mathrm{CH}, \mathrm{Ar}), 113.8(4 \times \mathrm{CH}, \mathrm{Ar}), 62.7(\mathrm{CH}), 61.9$ $\left(\mathrm{CH}_{2}\right), 60.6\left(\mathrm{CH}_{2}\right), 58.9\left(\mathrm{CH}_{2}\right), 55.3\left(2 \times \mathrm{OCH}_{3}\right), 55.2\left(\mathrm{CH}_{2}\right), 55.1$ $\left(\mathrm{CH}_{2}\right), \quad 52.7\left(\mathrm{CH}_{2}\right), 14.3\left(\mathrm{CH}_{3}\right)$. [ES-HRMS] calculated for $\mathrm{C}_{23} \mathrm{H}_{31} \mathrm{~N}_{2} \mathrm{O}_{4}$ : $399.2284[\mathrm{M}+\mathrm{H}]^{+}$. Found: $399.2270[\mathrm{M}+\mathrm{H}]^{+}$.

4.2.6.3. Ethyl 1,4-bis(3,5-dimethoxybenzyl)piperazine-2-carboxylate (14c). Synthesised according to the general procedure using $N, N^{\prime}-$ bis(3,5-dimethoxybenzyl)ethane-1,2-diamine 13c (1.5 g, 4.1 mmol). Yield: $68 \%$ as an orange solid, m.p. $58-60{ }^{\circ} \mathrm{C} .{ }^{1} \mathrm{H}$ NMR $\left(\mathrm{CDCl}_{3}\right): \delta 6.53(\mathrm{~d}, J=2.1 \mathrm{~Hz}, 2 \mathrm{H}, \mathrm{Ar}), 6.49(\mathrm{~d}, J=2.1 \mathrm{~Hz}, 2 \mathrm{H}, \mathrm{Ar})$, 6.37 (m, 2H, Ar), 4.20 (q, $J=7.1 \mathrm{~Hz}, 2 \mathrm{H}, \mathrm{CH}_{2} \mathrm{CH}_{3}$ ), 3.88 (d, $J=13.5$ $\left.\mathrm{Hz}, 1 \mathrm{H}, \mathrm{PhCH}_{2}\right), 3.797\left(\mathrm{~s}, 6 \mathrm{H}, 2 \times \mathrm{OCH}_{3}\right), 3.791\left(\mathrm{~s}, 6 \mathrm{H}, 2 \times \mathrm{OCH}_{3}\right)$, $3.61\left(\mathrm{~m}, 1 \mathrm{H}, \mathrm{CH}\right.$-piperazine), $3.52\left(\mathrm{~d}, J=13.5 \mathrm{~Hz}, 1 \mathrm{H}, \mathrm{CH}_{2} \mathrm{Ph}\right), 3.37$ (d, $J=13.6 \mathrm{~Hz}, 2 \mathrm{H}, \mathrm{CH}_{2} \mathrm{Ph}$ ), $3.15(\mathrm{~m}, 1 \mathrm{H}$, piperazine), $2.82(\mathrm{~m}, 1 \mathrm{H}$, piperazine), $2.59(\mathrm{~m}, 2 \mathrm{H}$, piperazine), $2.47(\mathrm{~m}, 2 \mathrm{H}$, piperazine), $1.25\left(\mathrm{t}, J=7.1 \mathrm{~Hz}, 3 \mathrm{H}, \mathrm{CH}_{2} \mathrm{CH}_{3}\right) .{ }^{13} \mathrm{C} \mathrm{NMR}\left(\mathrm{CDCl}_{3}\right): \delta 172.1$ (C, $\mathrm{C}=\mathrm{O}), 160.8\left(4 \times \mathrm{C}, \underline{\mathrm{C}}-\mathrm{OCH}_{3}\right), 140.8(\mathrm{C}, \mathrm{Ar}), 140.6(\mathrm{C}, \mathrm{Ar}), 106.8$ $(4 \times \mathrm{CH}, \mathrm{Ar}), 99.1(\mathrm{CH}, \mathrm{Ar}), 99.0(\mathrm{CH}, \mathrm{Ar}), 62.7\left(\mathrm{CH}_{2}\right), 62.4(\mathrm{CH})$, $60.3\left(\mathrm{CH}_{2}\right), 59.6\left(\mathrm{CH}_{2}\right), 55.5\left(\mathrm{CH}_{2}\right), 55.3\left(4 \times \mathrm{OCH}_{3}\right), 53.2\left(\mathrm{CH}_{2}\right)$, $48.5\left(\mathrm{CH}_{2}\right), 14.2\left(\mathrm{CH}_{3}\right)$. [AP-HRMS] calculated for $\mathrm{C}_{25} \mathrm{H}_{35} \mathrm{~N}_{2} \mathrm{O}_{6}$ : 459.2495 $[\mathrm{M}+\mathrm{H}]^{+}$. Found: $459.2475[\mathrm{M}+\mathrm{H}]^{+}$.

\subsubsection{General procedure for the synthesis of [1,4-bis(substituted benzyl)piperazin-2-yl]methanol (15)}

A suspension of $\mathrm{LiAlH}_{4}$ (4 eq, $1 \mathrm{M}$ in $\mathrm{Et}_{2} \mathrm{O}$ ) was diluted with dry $\mathrm{Et}_{2} \mathrm{O}\left(15 \mathrm{~mL} / 11 \mathrm{mmol} \mathrm{LiAlH}_{4}\right)$ then added to a solution of 1,4-bis (substituted-benzyl)piperazine-2-carboxylic acid ethyl ester 14 (1 eq) in dry $\mathrm{Et}_{2} \mathrm{O}(20 \mathrm{~mL} / 6 \mathrm{mmol}$ of $\mathbf{1 4})$ slowly over $1 \mathrm{~h}$ at $0{ }^{\circ} \mathrm{C}$.
The reaction was stirred overnight at room temperature, cooled to $0{ }^{\circ} \mathrm{C}$ and treated carefully with saturated aqueous $\mathrm{NaHCO}_{3}$ until cessation of effervescence. The solution was extracted with ethyl acetate $(3 \times 50 \mathrm{~mL})$, the organic layer was dried $\left(\mathrm{MgSO}_{4}\right)$, concentrated under reduced and purified by flash chromatography using gradient elution $\mathrm{CH}_{2} \mathrm{Cl}_{2}: \mathrm{CH}_{3} \mathrm{OH}$, and the product appeared at $2 \%$ methanol.

4.2.7.1. 1,4-Dibenzylpiperazin-2-yl-methanol $(\mathbf{1 5 a})^{28}$. Synthesised according to the general procedure using 1,4-dibenzylpiperazine2-carboxylic acid ethyl ester 14a (3.1 g, $9.1 \mathrm{mmol}$ ). Yield: $92 \%$ as a yellow oil. ${ }^{1} \mathrm{H} \mathrm{NMR}\left(\mathrm{CDCl}_{3}\right): \delta 7.35(\mathrm{~m}, 8 \mathrm{H}, \mathrm{Ar}), 7.28(\mathrm{~m}, 2 \mathrm{H}$, Ar), 4.05 (dd, $J=2.5 \mathrm{~Hz}, 10.9 \mathrm{~Hz}, 2 \mathrm{H}, \mathrm{CH}_{2}$ ), 3.65 (dd, $J=2.6,11.2$ $\mathrm{Hz}, 1 \mathrm{H}), 3.43$ (s, 2H, CH $), 3.50(\mathrm{~d}, J=13.5 \mathrm{~Hz}, 1 \mathrm{H}), 2.97(\mathrm{~m}, 1 \mathrm{H}$, piperazine), 2.76 (dd, 2.6, $10.8 \mathrm{~Hz}, 1 \mathrm{H}$, piperazine), $2.68(\mathrm{~m}, 1 \mathrm{H}$, piperazine), $2.58(\mathrm{~m}, 2 \mathrm{H}$, piperazine $), 2.48$ ( $\mathrm{m}, 1 \mathrm{H}$, piperazine), $2.40\left(\mathrm{~m}, 1 \mathrm{H}\right.$, piperazine). ${ }^{13} \mathrm{C}$ NMR $\left(\mathrm{CDCl}_{3}\right): \delta 138.5(\mathrm{C}, \mathrm{Ar}), 137.6$ (C, Ar), $129.2(2 \times \mathrm{CH}, \mathrm{Ar}), 128.7(2 \times \mathrm{CH}, \mathrm{Ar}), 128.4(2 \times \mathrm{CH}, \mathrm{Ar})$, $127.5(2 \times \mathrm{CH}, \mathrm{Ar}), 127.4(2 \times \mathrm{CH}, \mathrm{Ar}), 63.0\left(\mathrm{CH}_{2}\right), 62.1\left(\mathrm{CH}_{2}\right)$, $58.5(\mathrm{CH}), 58.1\left(\mathrm{CH}_{2}\right), 56.0\left(\mathrm{CH}_{2}\right), 53.0\left(\mathrm{CH}_{2}\right), 50.0\left(\mathrm{CH}_{2}\right)$.

\subsubsection{1,4-Bis(4-methoxybenzyl)piperazin-2-yl]methanol (15b) ${ }^{29}$.}

Synthesised according to the general procedure using 1,4-bis (4-methoxybenzyl)piperazine-2-carboxylic acid ethyl ester 14b (1.9 mL, $4.7 \mathrm{mmol}$ ). Yield: $62 \%$ as a beige solid, m.p: $94-96{ }^{\circ} \mathrm{C} .{ }^{1} \mathrm{H}$ $\operatorname{NMR}\left(\mathrm{CDCl}_{3}\right): \delta 7.22(\mathrm{t}, J=8.0 \mathrm{~Hz}, 2 \mathrm{H}, \mathrm{Ar}), 6.85(\mathrm{dd}, J=2.0,9.0 \mathrm{~Hz}$, $2 \mathrm{H}, \mathrm{Ar}$ ), $3.98\left(\mathrm{~m}, 2 \mathrm{H}, \mathrm{CH}_{2}\right), 3.77\left(\mathrm{~s}, 6 \mathrm{H}, 2 \times \mathrm{OCH}_{3}\right), 3.75$ (s, obscured $\left.1 \mathrm{H}, \mathrm{CH}_{2}\right), 3.61\left(\mathrm{~m}, 1 \mathrm{H}, \mathrm{CH}_{2}\right), 3.37\left(\mathrm{~m}, 2 \mathrm{H}, \mathrm{CH}_{2}\right), 2.92(\mathrm{~m}, 1 \mathrm{H}$, piperazine), $2.71-2.33\left(\mathrm{~m}, 6 \mathrm{H}\right.$, piperazine). ${ }^{13} \mathrm{C}$ NMR $\left(\mathrm{CDCl}_{3}\right): \delta 158.8$ $\left(\mathrm{C}, \underline{\mathrm{C}}-\mathrm{OCH}_{3}\right), 158.7\left(\mathrm{C}, \mathrm{C}-\mathrm{OCH}_{3}\right), 130.3(2 \times \mathrm{CH}, \mathrm{Ar}), 130.2(\mathrm{C}, \mathrm{Ar})$, $129.9(2 \times \mathrm{CH}, \mathrm{Ar}), 129.7$ (C, Ar), $114.0(\mathrm{CH}, \mathrm{Ar}), 62.8\left(\mathrm{CH}_{2}\right), 62.5$ $\left(\mathrm{CH}_{2}\right), 58.9(\mathrm{CH}), 57.8\left(\mathrm{CH}_{2}\right), 56.1\left(\mathrm{CH}_{2}\right), 55.2\left(\mathrm{CH}_{3}\right), 52.4\left(\mathrm{CH}_{2}\right)$, $49.9\left(\mathrm{CH}_{2}\right)$.

\subsubsection{3. [1,4-Bis(3,5-dimethoxybenzyl)piperazin-2-yl]methanol (15c).}

Synthesised according to the general procedure using 1,4-bis (3,5-dimethoxybenzyl)piperazine-2-carboxylic acid ethyl ester 14c (1.17 g, $2.5 \mathrm{mmol})$. Yield: $50 \%$ as a yellow oil. ${ }^{1} \mathrm{H}$ NMR $\left(\mathrm{CDCl}_{3}\right)$ : $\delta 6.41(\mathrm{~d}, J=2.2 \mathrm{~Hz}, 2 \mathrm{H}, \mathrm{Ar}), 6.39(\mathrm{~d}, J=2.2 \mathrm{~Hz}, 2 \mathrm{H}, \mathrm{Ar}), 6.26(\mathrm{~m}, 2 \times$ $\mathrm{CH}, \mathrm{Ar}), 3.90$ (dd, $J=3.3,11.3 \mathrm{~Hz}, 1 \mathrm{H}), 3.82(\mathrm{~d}, J=13.1 \mathrm{~Hz}, 1 \mathrm{H}), 3.68$ $\left(\mathrm{s}, 12 \mathrm{H}, 4 \times \mathrm{OCH}_{3}\right), 3.35(\mathrm{~d}, J=13.5 \mathrm{~Hz}, 1 \mathrm{H}), 3.35(\mathrm{~m}, 3 \mathrm{H}), 2.89(\mathrm{~m}$, $1 \mathrm{H}$, piperazine), $2.58(\mathrm{~m}, 2 \mathrm{H}$, piperazine), $2.60(\mathrm{~m}, 1 \mathrm{H}$, piperazine), $2.41\left(\mathrm{~m}, 2 \mathrm{H}\right.$, piperazine), 2.33 ( $\mathrm{m}, 1 \mathrm{H}, \mathrm{CH}$-piperazine). ${ }^{13} \mathrm{C}$ NMR $\left(\mathrm{CDCl}_{3}\right): \delta 160.9(2 \times \mathrm{C}), 160.8(2 \times \mathrm{C}), 141.0(\mathrm{C}), 140.0(\mathrm{C}), 107.2$ ( $2 \times \mathrm{CH}, \mathrm{Ar}), 106.9(2 \times \mathrm{CH}, \mathrm{Ar}), 99.3(\mathrm{CH}, \mathrm{Ar}), 99.0(\mathrm{CH}, \mathrm{Ar}), 63.2$ $\left(\mathrm{CH}_{2}\right), \quad 62.1\left(\mathrm{CH}_{2}\right), \quad 58.9(\mathrm{CH}), 58.2\left(\mathrm{CH}_{2}\right), \quad 58.0\left(\mathrm{CH}_{2}\right), \quad 55.3$ $\left(4 \times \mathrm{OCH}_{3}\right), 52.4\left(\mathrm{CH}_{2}\right), 49.89\left(\mathrm{CH}_{2}\right)$. [AP-HRMS] calculated for $\mathrm{C}_{23} \mathrm{H}_{33} \mathrm{~N}_{2} \mathrm{O}_{5}$ : $417.2389[\mathrm{M}+\mathrm{H}]^{+}$. Found: $417.2394[\mathrm{M}+\mathrm{H}]^{+}$.

\subsubsection{General procedure for the synthesis of 1,4-Bis(substituted-}

benzyl)-2 chloromethylpiperazine (16)

To 1,4-bis(substituted benzyl)piperazin-2-yl]-methanol 15 (1 eq) in dry toluene $\left(20 \mathrm{~mL} / 1 \mathrm{mmol}\right.$ of $\mathbf{1 5}$ ) was added $\mathrm{SOCl}_{2}$ (2 eq) slowly while cooling in an ice bath. The reaction mixture was refluxed overnight at $80^{\circ} \mathrm{C}$ then cooled to room temperature and washed with saturated aqueous $\mathrm{NaHCO}_{3}(3 \times 30 \mathrm{~mL})$, brine $(2 \times 20 \mathrm{~mL})$ and water $(2 \times 20 \mathrm{~mL})$. The organic layer was dried $\left(\mathrm{MgSO}_{4}\right)$ and concentrated under reduced pressure.

4.2.8.1. 1,4-Dibenzyl-2-chloromethylpiperazine (16a). Synthesised according to the general procedure using (1,4-dibenzylpiperazin2 -yl)methanol 15a ( $2 \mathrm{~g}, 6.7 \mathrm{mmol}$ ). The product was pure enough to proceed to the next step. Yield: $76 \%$ as a yellowish orange oil. ${ }^{1} \mathrm{H} \mathrm{NMR}\left(\mathrm{CDCl}_{3}\right): \delta 7.39(\mathrm{~m}, 8 \mathrm{H}, \mathrm{Ar}), 7.31(\mathrm{~m}, 2 \mathrm{H}, \mathrm{Ar}), 3.96(\mathrm{~m}$, $\left.2 \mathrm{H}, \mathrm{CH}_{2}\right), 3.76(\mathrm{dd}, J=2.8,11.1 \mathrm{~Hz}, 1 \mathrm{H}), 3.59\left(\mathrm{~d}, J=6 \mathrm{~Hz}, 2 \mathrm{H}, \mathrm{CH}_{2}\right)$, 
$3.56(\mathrm{~d}, J=13.3 \mathrm{~Hz}, 1 \mathrm{H}), 2.92(\mathrm{~m}, 1 \mathrm{H}$, piperazine), $2.77(\mathrm{~m}, 1 \mathrm{H}$, piperazine), $2.70(\mathrm{~d}, J=4.2 \mathrm{~Hz}, 2 \mathrm{H}$, piperazine), $2.52(\mathrm{~m}, 1 \mathrm{H}$, piperazine), 2.44 (d, $J=7.4 \mathrm{~Hz}, 2 \mathrm{H}$, piperazine). ${ }^{13} \mathrm{C} \mathrm{NMR}\left(\mathrm{CDCl}_{3}\right): \delta 138.6$ (C), 138.1 (C), $129.4(2 \times \mathrm{CH}, \mathrm{Ar}), 129.3(2 \times \mathrm{CH}, \mathrm{Ar}), 128.7(2 \times \mathrm{CH}$, $\mathrm{Ar}), 128.5(2 \times \mathrm{CH}, \mathrm{Ar}), 127.3(2 \times \mathrm{CH}, \mathrm{Ar}), 62.9\left(\mathrm{CH}_{2}\right), 62.0(\mathrm{CH})$, $60.4\left(\mathrm{CH}_{2}\right), 58.2\left(\mathrm{CH}_{2}\right), 55.8\left(\mathrm{CH}_{2}\right), 49.1\left(\mathrm{CH}_{2}\right), 42.6\left(\mathrm{CH}_{2}\right)$.

\subsubsection{2-Chloromethyl-1,4-bis(4-methoxybenzyl)piperazine (16b).}

Synthesised according to the general procedure using 1,4-bis (4-methoxybenzyl)piperazin-2-yl]methanol 15b (1 g, $2.8 \mathrm{mmol}$ ). Obtained as a white crystalline solid after recrystallisation from methanol. Yield: $31 \%$, m.p. $76-82{ }^{\circ} \mathrm{C} .{ }^{1} \mathrm{H}$ NMR $\left(\mathrm{CDCl}_{3}\right): \delta 7.26(\mathrm{~m}$, $4 \mathrm{H}, \mathrm{Ar}), 7.87(\mathrm{~m}, 4 \mathrm{H}, \mathrm{Ar}), 3.91\left(\mathrm{~m}, 2 \mathrm{H}, \mathrm{CH}_{2}\right), 3.82\left(\mathrm{~s}, 3 \mathrm{H}, \mathrm{OCH}_{3}\right)$, $3.81\left(\mathrm{~s}, 3 \mathrm{H}, \mathrm{OCH}_{3}\right), 3.70(\mathrm{dd}, J=2.6,11.2 \mathrm{~Hz}, 1 \mathrm{H}), 3.50(\mathrm{~m}, 2 \mathrm{H}$, $\left.\mathrm{CH}_{2}\right), 3.42(\mathrm{~d}, J=13.1 \mathrm{~Hz}, 1 \mathrm{H}), 2.87(\mathrm{~m}, 1 \mathrm{H}$, piperazine), $2.73(\mathrm{~m}$, $1 \mathrm{H}$, piperazine), $2.63(\mathrm{~m}, 2 \mathrm{H}$, piperazine $), 2.50(\mathrm{~m}, 1 \mathrm{H}$, piperazine), $2.4\left(\mathrm{~d}, J=6.4 \mathrm{~Hz}, 2 \mathrm{H}\right.$, piperazine). ${ }^{13} \mathrm{C}$ NMR $\left(\mathrm{CDCl}_{3}\right): \delta 158.9(\mathrm{C})$, 158.8 (C), $130.4(2 \times \mathrm{CH}, \mathrm{Ar}), 130.2(2 \times \mathrm{C}), 130.0(2 \times \mathrm{CH}, \mathrm{Ar})$, $113.9(4 \times \mathrm{CH}, \mathrm{Ar}), 62.1\left(\mathrm{CH}_{2}\right), 59.9(\mathrm{CH}), 57.4\left(\mathrm{CH}_{2}\right), 55.3\left(\mathrm{CH}_{3}\right)$, $55.1\left(\mathrm{CH}_{2}\right), \quad 52.5\left(\mathrm{CH}_{2}\right), 48.9\left(\mathrm{CH}_{2}\right), 42.7\left(\mathrm{CH}_{2}\right)$. [AP-HRMS] calculated for $\mathrm{C}_{21} \mathrm{H}_{28} \mathrm{ClN}_{2} \mathrm{O}_{2}$ : $375.1839[\mathrm{M}+\mathrm{H}]^{+}$. Found: 375.1831 $[\mathrm{M}+\mathrm{H}]^{+}$.

4.2.9. General procedure for the synthesis of 1,4-bis(substituted-benzyl)2-imidazol-1-ylmethyl-piperazine and 1,4-bis(substituted-benzyl)-2[1,2,4]triazol-1-ylmethyl-piperazine (17)

To a solution of imidazole or triazole (4 eq) in dry DMF ( $5 \mathrm{~mL} / 2.5 \mathrm{mmol}$ of starting material) was added $\mathrm{NaH}$ (60\% dispersion in mineral oil, $4 \mathrm{eq}$ ). After refluxing the mixture for $1 \mathrm{~h}$ at 40 ${ }^{\circ} \mathrm{C}$, a solution of 1,4-bis(substituted-benzyl)-2-chloromethyl-piperazine 16 (1 eq) in dry DMF ( $5 \mathrm{~mL} / 2.5 \mathrm{mmol}$ of 16) and $\mathrm{KI}(1.08 \mathrm{eq})$ was added to the mixture and refluxed overnight at $60^{\circ} \mathrm{C}$. The reaction was cooled, diluted with EtOAc $(100 \mathrm{~mL})$ and washed with brine $(2 \times 10 \mathrm{~mL})$ and water $(2 \times 10 \mathrm{~mL})$, the organic layer was dried $\left(\mathrm{MgSO}_{4}\right)$, evaporated and the resulting residue was further purified.

4.2.9.1. 1,4-Dibenzyl-2-imidazol-1-yl-methylpiperazine (17a). Synthesised according to the general procedure using 1,4-dibenzyl2-chloromethylpiperazine 16a $(0.8 \mathrm{~g}, 2.5 \mathrm{mmol})$, imidazole $(0.66$ $\mathrm{g}, 10 \mathrm{mmol}$ ). The product was purified by flash chromatography using gradient elution of $\mathrm{CH}_{2} \mathrm{Cl}_{2}: \mathrm{CH}_{3} \mathrm{OH}$, the product appeared at $2 \%$ methanol. Yield: $63 \%$ as a yellowish orange semi-solid. ${ }^{1} \mathrm{H}$ NMR $\left(\mathrm{CDCl}_{3}\right): \delta 7.32(\mathrm{~m}, 8 \mathrm{H}, \mathrm{Ar}), 7.25(\mathrm{~s}, 1 \mathrm{H}$, imidazole), $6.96(\mathrm{~s}$, $1 \mathrm{H}$, imidazole), $6.64(\mathrm{~s}, 1 \mathrm{H}$, imidazole), $4.30(\mathrm{~m}, 1 \mathrm{H}), 4.15$ (dd, $J=4.0,13.7 \mathrm{~Hz}, 1 \mathrm{H}), 3.89$ (d, $J=13.4 \mathrm{~Hz}, 1 \mathrm{H}), 3.67$ (dd, $J=5.0$, $18.5 \mathrm{~Hz}, 1 \mathrm{H}), 3.53(\mathrm{~d}, J=12.8 \mathrm{~Hz}, 1 \mathrm{H}), 3.37$ (d, $J=12.8 \mathrm{~Hz}, 1 \mathrm{H}$ ), $2.87(\mathrm{~m}, 2 \mathrm{H}$, piperazine), $2.56(\mathrm{~m}, 2 \mathrm{H}$, piperazine), $2.41(\mathrm{~m}, 1 \mathrm{H}$, piperazine), 2.3 (d, $J=3.4 \mathrm{~Hz}, 2 \mathrm{H}$, piperazine). ${ }^{13} \mathrm{C} \mathrm{NMR}\left(\mathrm{CDCl}_{3}\right): \delta$ 138.3 (C, Ar), 138.3 (C, Ar), 137.6 ( $\mathrm{CH}$, imidazole), $129.8(2 \times \mathrm{CH}$, Ar), $129.0(\mathrm{CH}$, imidazole $), 128.6(2 \times \mathrm{CH}, \mathrm{Ar}), 128.5(2 \times \mathrm{CH}, \mathrm{Ar})$, $128.4(2 \times \mathrm{CH}, \mathrm{Ar}), 127.4(2 \times \mathrm{CH}, \mathrm{Ar}), 119.5(\mathrm{CH}$, imidazole $), 63.3$ $\left(2 \times \mathrm{CH}_{2}\right), 58.5(\mathrm{CH}), 58.3\left(2 \times \mathrm{CH}_{2}\right), 52.5\left(2 \times \mathrm{CH}_{2}\right)$. [AP-HRMS] calculated for $\mathrm{C}_{22} \mathrm{H}_{27} \mathrm{~N}_{4}$ : $347.2236[\mathrm{M}+\mathrm{H}]^{+}$. Found: 347.2222 $[\mathrm{M}+\mathrm{H}]^{+}$.

4.2.9.2.

1,4-Dibenzyl-2-[1,2,4]triazol-1-yl-methylpiperazine (17b). Synthesised according to the general procedure using 1,4dibenzyl-2-chloromethylpiperazine 16a $(0.8 \mathrm{~g}, 2.5 \mathrm{mmol})$, triazole $(0.66 \mathrm{~g}, 10 \mathrm{mmol})$. The product was purified by flash chromatography using gradient elution of $\mathrm{CH}_{2} \mathrm{Cl}_{2}: \mathrm{CH}_{3} \mathrm{OH}$, the product appeared at $2 \%$ methanol. Yield: $57 \%$ as a yellowish orange oil. ${ }^{1} \mathrm{H}$ NMR $\left(\mathrm{CDCl}_{3}\right): \delta 7.88(\mathrm{~s}, 1 \mathrm{H}$, triazole), $7.81(\mathrm{~s}, 1 \mathrm{H}$, triazole $), 7.31(\mathrm{~m}$, $10 \mathrm{H}, \mathrm{Ar}), 4.54(\mathrm{~s}, 1 \mathrm{H}), 4.47$ (dd, J=4.6, $13.6 \mathrm{~Hz}, 1 \mathrm{H}), 3.85$ $(\mathrm{d}, J=13.4 \mathrm{~Hz}, 1 \mathrm{H}), 3.75$ (d, $J=13.4 \mathrm{~Hz}, 1 \mathrm{H}), 3.58(\mathrm{~d}, J=11.0 \mathrm{~Hz}$, $1 \mathrm{H}), 3.40(\mathrm{~d}, J=12.2 \mathrm{~Hz}, 1 \mathrm{H}), 3.18(\mathrm{~m}, 1 \mathrm{H}$, piperazine), 2.85 (s, $1 \mathrm{H}$, piperazine), 2.42 ( $\mathrm{s}, 2 \mathrm{H}$, piperazine), 2.57 ( $\mathrm{s}, 2 \mathrm{H}$, piperazine), $2.32\left(\mathrm{~d}, J=9.1 \mathrm{~Hz}, 1 \mathrm{H}\right.$, piperazine). ${ }^{13} \mathrm{C} \mathrm{NMR}\left(\mathrm{CDCl}_{3}\right): \delta 151.9(\mathrm{CH}$, triazole), $143.8(\mathrm{CH}$, triazole $), 138.6(2 \times \mathrm{C}), 129.3(2 \times \mathrm{CH}, \mathrm{Ar})$, $128.8(2 \times \mathrm{CH}, \mathrm{Ar}), 128.6(2 \times \mathrm{CH}, \mathrm{Ar}), 128.4(2 \times \mathrm{CH}, \mathrm{Ar}), 127.3$ $(2 \times \mathrm{CH}, \mathrm{Ar}), \quad 62.8\left(2 \times \mathrm{CH}_{2}\right), \quad 58.3\left(2 \times \mathrm{CH}_{2}\right), \quad 57.9(\mathrm{CH}), \quad 52.3$ $\left(2 \times \mathrm{CH}_{2}\right)$. [ES-HRMS] calculated for $\mathrm{C}_{21} \mathrm{H}_{26} \mathrm{~N}_{5}: 348.4646[\mathrm{M}+\mathrm{H}]^{+}$. Found: $348.4638[\mathrm{M}+\mathrm{H}]^{+}$.

4.2.9.3. 1,4-Bis(4-methoxybenzyl)-2-[1,2,4]triazol-1-ylmethyl-piperazine $(\mathbf{1 7} \mathbf{c})$. Synthesised according to the general procedure using 2-chloromethyl-1,4-bis(4-methoxybenzyl)piperazine $\mathbf{1 6 b}$ ( $0.31 \mathrm{~g}$, $0.8 \mathrm{mmol})$, triazole $(0.21 \mathrm{~g}, 3.2 \mathrm{mmol})$. The product was purified by preparative TLC using $\mathrm{CH}_{2} \mathrm{Cl}_{2}: \mathrm{CH}_{3} \mathrm{OH} 95: 5 \mathrm{v} / \mathrm{v}$ as eluent. Yield: $36 \%$ as a yellowish orange oil. ${ }^{1} \mathrm{H}$ NMR $\left(\mathrm{CDCl}_{3}\right): \delta 7.88(\mathrm{~s}, 2 \mathrm{H}$, triazole), 7.20 (d, $J=8.0 \mathrm{~Hz}, 2 \mathrm{H}, \mathrm{Ar}$ ), 7.18 (d, $J=8.6 \mathrm{~Hz}, 2 \mathrm{H}, \mathrm{Ar}), 6.86$ (m, $4 \mathrm{H}, \mathrm{Ar}$ ), 4.49 (d, $J=4.7 \mathrm{~Hz}, 1 \mathrm{H}), 4.46$ (dd, $J=4.7,13.7 \mathrm{~Hz}, 1 \mathrm{H}), 3.82$ $\left(\mathrm{s}, 3 \mathrm{H}, \mathrm{CH}_{3}\right), 3.80\left(\mathrm{~s}, 3 \mathrm{H}, \mathrm{CH}_{3}\right), 3.78$ (obscured d, $\left.1 \mathrm{H}\right), 3.66(\mathrm{~d}, J=5.0$ $\mathrm{Hz}, 1 \mathrm{H}), 3.49(\mathrm{~d}, J=11.9 \mathrm{~Hz}, 1 \mathrm{H}), 3.35(\mathrm{~d}, J=12.7 \mathrm{~Hz}, 1 \mathrm{H}), 3.17(\mathrm{~m}$, $1 \mathrm{H}$, piperazine), $2.85(\mathrm{~m}, 1 \mathrm{H}$, piperazine), $2.52(\mathrm{~d}, J=11.5 \mathrm{~Hz}, 2 \mathrm{H}$, piperazine), 2.38 (d, $J=8.8 \mathrm{~Hz}, 2 \mathrm{H}$, piperazine), 2.28 (dd, $J=3.7$, $11.4 \mathrm{~Hz}, 1 \mathrm{H}$, piperazine). ${ }^{13} \mathrm{C}$ NMR $\left(\mathrm{CDCl}_{3}\right): \delta 159.0\left(\mathrm{C}, \mathrm{C}-\mathrm{OCH}_{3}\right)$, $158.8\left(\mathrm{C}, \mathrm{C}-\mathrm{OCH}_{3}\right), 151.8(\mathrm{CH}$, triazole $), 143.8(\mathrm{CH}$, triazole $)$, $132.0(\mathrm{CH}, \mathrm{Ar}), 129.9(2 \times \mathrm{CH}, \mathrm{Ar}), 114.1(4 \times \mathrm{CH}, \mathrm{Ar}), 62.2(2 \times$ $\left.\mathrm{CH}_{2}\right), 57.8(\mathrm{CH}), 57.6\left(2 \times \mathrm{CH}_{2}\right), 55.3\left(\mathrm{CH}_{3}\right), 55.3\left(\mathrm{CH}_{3}\right), 52.0(2 \times$ $\mathrm{CH}_{2}$ ). [ES-HRMS] calculated for $\mathrm{C}_{23} \mathrm{H}_{30} \mathrm{~N}_{5} \mathrm{O}_{2}: 408.2394[\mathrm{M}+\mathrm{H}]^{+}$. Found: $408.2385[\mathrm{M}+\mathrm{H}]^{+}$.

4.2.9.4. 1,4-Bis(3,5-dimethoxybenzyl)2-imidazole-1-ylmethyl-piperazine (17d). To a solution of [1,4-bis(3,5-dimethoxybenzyl)-piperazin-2-yl]-methanol 15c $(0.25 \mathrm{~g}, 0.6 \mathrm{mmol})$ in dry $\mathrm{CH}_{2} \mathrm{Cl}_{2}(30 \mathrm{~mL})$ was added methanesulfonylchloride $(0.05 \mathrm{~mL}, 0.69 \mathrm{mmol})$ and triethylamine $(0.16 \mathrm{~mL}, 1.18 \mathrm{mmol})$ at $0{ }^{\circ} \mathrm{C}$. The resulting mixture was stirred at room for $2 \mathrm{~h}$. After quenching the reaction with water $(20 \mathrm{~mL})$, the organic phase was washed with water $(2 \times$ $20 \mathrm{~mL})$, dried $\left(\mathrm{MgSO}_{4}\right)$ and evaporated under vacuum. The resulting methane sulfonate derivative was added to a solution of imidazole sodium salt (prepared from imidazole $(0.12 \mathrm{~g}, 1.7 \mathrm{mmol})$ and $\mathrm{NaH} 60 \%$ dispersion in mineral oil $(0.04 \mathrm{~g}, 1.7 \mathrm{mmol})$ in dry toluene $(20 \mathrm{~mL})$, previously refluxed at $40{ }^{\circ} \mathrm{C}$ for $1 \mathrm{~h}$ ) and the reaction mixture refluxed overnight at $115^{\circ} \mathrm{C}$. The reaction was cooled to room temperature and washed with water $(5 \times 25 \mathrm{~mL})$. The organic layer was separated, dried $\left(\mathrm{MgSO}_{4}\right)$, evaporated under vacuum and purified by preparative TLC using $\mathrm{CH}_{2} \mathrm{Cl}_{2}: \mathrm{CH}_{3} \mathrm{OH} 98: 2 \mathrm{v} / \mathrm{v}$. Yield: $14 \%$ as an oily yellow orange solid. ${ }^{1} \mathrm{H} \mathrm{NMR}\left(\mathrm{CDCl}_{3}\right): \delta 7.25$ (s, 1H, imidazole), 6.88 (s, 1H, imidazole), 6.31 (s, 1H, imidazole), $6.42(\mathrm{~m}, 4 \mathrm{H}, \mathrm{Ar}), 6.31(\mathrm{~m}, 2 \mathrm{H}, \mathrm{Ar}), 4.21(\mathrm{~m}, 1 \mathrm{H}), 4.11(\mathrm{dd}, J=4.3$, $13.8 \mathrm{~Hz}, 1 \mathrm{H}), 3.71\left(\mathrm{~s}, 6 \mathrm{H}, 2 \times \mathrm{OCH}_{3}\right), 3.70\left(\mathrm{~s}, 6 \mathrm{H}, 2 \times \mathrm{OCH}_{3}\right), 3.69$ (d, $J=10.3 \mathrm{~Hz}, 1 \mathrm{H}), 3.38(\mathrm{~m}, 1 \mathrm{H}), 3.25(\mathrm{~d}, J=13.0 \mathrm{~Hz}, 2 \mathrm{H}), 2.81$ ( $\mathrm{m}, 1 \mathrm{H}$, piperazine), $2.68(\mathrm{~m}, 1 \mathrm{H}$, piperazine), $2.55(\mathrm{~m} .1 \mathrm{H}$, piperazine), 2.48 ( $\mathrm{m}, 2 \mathrm{H}$, piperazine), 2.35 ( $\mathrm{m}, 1 \mathrm{H}$, piperazine), 2.23 (m, $1 \mathrm{H}$, piperazine). ${ }^{13} \mathrm{C}$ NMR $\left(\mathrm{CDCl}_{3}\right): \delta 160.9(2 \times \mathrm{C}), 160.85(2$ $\times \mathrm{C}), 140.9(\mathrm{C}), 140.6(\mathrm{C}), 137.6(\mathrm{CH}$, imidazole $), 129.2(\mathrm{CH}$, imidazole), 119.5 ( $\mathrm{CH}$, imidazole), $107.1(2 \times \mathrm{CH}, \mathrm{Ar}), 106.3(2 \times \mathrm{CH}, \mathrm{Ar})$, $98.9(\mathrm{CH}, \mathrm{Ar}), 98.8(\mathrm{CH}, \mathrm{Ar}), 60.4\left(2 \times \mathrm{CH}_{2}\right), 58.4(\mathrm{CH}), 58.1(2 \times$ $\left.\mathrm{CH}_{2}\right), 55.3\left(4 \times \mathrm{OCH}_{3}\right), 52.3\left(2 \times \mathrm{CH}_{2}\right)$. [ES-HRMS] calculated for $\mathrm{C}_{26} \mathrm{H}_{35} \mathrm{~N}_{4} \mathrm{O}_{4}: 467.2653[\mathrm{M}+\mathrm{H}]^{+}$. Found: $467.2641[\mathrm{M}+\mathrm{H}]^{+}$.

\subsection{Spectral binding Assay}

CYP121A1 protein was expressed and purified as described previously. ${ }^{30}$ Ligand binding assays were performed by spectrophotometric titration using a Cary 60 UV-visible scanning spectrophotometer (Agilent, UK) and a $1 \mathrm{~cm}$ path length quartz cuvette, recording spectra between 250 and $800 \mathrm{~nm}$. Titrations were done with $3-4 \mu \mathrm{M}$ CYP121A 1 at $28{ }^{\circ} \mathrm{C}$ in $100 \mathrm{mM}$ potassium phosphate (KPi) buffer, $200 \mathrm{mM} \mathrm{KCl}$, pH 7.85 with $0.004 \%$ Triton X- 
100. Ligand stocks solutions were prepared in dimethylsulfoxide (DMSO). Ligands were added in successive small volumes (typically $0.05-0.2 \mu \mathrm{L}$ aliquots) from concentrated stock solutions to the protein in a $1 \mathrm{~mL}$ final volume. Spectral measurements were taken before ligand addition, and following addition of each aliquot of ligand. Difference spectra at each stage in the titration were obtained by subtraction of the initial ligand-free enzyme spectrum from subsequent spectra collected after each addition of ligand. From the difference spectra, a pair of wavelengths were identified and defined as the absorbance maximum $\left(A_{\text {peak }}\right)$ and minimum $\left(A_{\text {trough }}\right)$. The overall absorbance change $\left(A_{\max }\right)$ was calculated by subtracting the minimum from the maximum absorbance for every spectrum collected after each aliquot addition. Graphs of $\left(A_{\max }\right.$, $\Delta \Delta$ Absorbance) against [ligand] were plotted for each ligand. Titrations were repeated in triplicate and the final $K_{\mathrm{d}}$ value was determined from the average values across the three sets. The $K_{\mathrm{d}}$ values were determined from these plots of $\Delta \Delta$ Absorbance against ligand concentration, and by fitting the data using either a standard hyberbolic function (Eq. (1)) or the Hill equation (Eq. (2)) using Origin software (OriginLab, Northampton, MA).

$\mathrm{A}_{\mathrm{obs}}=\left(\mathrm{A}_{\max } * \mathrm{~L} /\left(K_{\mathrm{d}}+\mathrm{L}\right)\right)$

In Eq. (1) (the standard hyperbolic function, essentially the Michaelis-Menten function adapted for ligand binding), $A_{o b s}$ is the observed absorbance change at ligand concentration $L, A_{\max }$ is the maximal absorbance change observed at ligand saturation, and $K_{\mathrm{d}}$ is the dissociation constant for the binding of the ligand (the substrate concentration at which $A_{o b s}=0.5 \times A_{\max }$ ).

$\mathrm{A}_{\mathrm{obs}}=\left(\mathrm{A}_{\max } \times \mathrm{L}^{\mathrm{n}}\right) /\left(K^{\mathrm{n}}+\mathrm{L}^{\mathrm{n}}\right)$

In Eq. (2) (the sigmoidal Hill equation), $A_{o b s}$ is the observed absorbance change at ligand concentration L, $A_{\max }$ is the absorbance change at ligand saturation, $K$ is the apparent dissociation constant, and $\mathrm{n}$ is the Hill coefficient, a value describing the apparent extent of cooperativity observed in ligand binding.

\subsection{EPR spectroscopy}

Continuous wave X-band EPR spectra of ligand-free CYP121A1 $(110 \mu \mathrm{M})$ as well as for CYP121A1 in complex with compounds from Series A, B and C (2 mM) were recorded using a Bruker ELEXSYS E500 EPR spectrometer with an ER 4122SHQ Super High Q cavity. Temperature was controlled with an ESR900 cryostat (Oxford Instruments, Abingdon UK). Spectra were recorded at 10 $\mathrm{K}$, microwave power at $0.5 \mathrm{~mW}$, modulation frequency $100 \mathrm{kHz}$ and modulation amplitude at $7 \mathrm{G}$. Samples were prepared in 100 mM HEPES, $100 \mathrm{mM} \mathrm{NaCl}$ with $0.004 \%$ Triton X-100 at $\mathrm{pH}$ 7.6. Ligands were added from concentrated stock solutions in DMSO to a final concentration of $2 \mathrm{mM}$ and samples incubated for 20 min at room temperature. Samples were centrifuged briefly to remove any particulate matter prior to transfer to EPR tubes and freezing in liquid nitrogen.

\subsection{Antimycobacterial activity Assay}

M. tuberculosis $\mathrm{H}_{37} \mathrm{Rv}$ was grown in $7 \mathrm{H} 9$ liquid medium with $10 \%$ OADC enrichment. The bacteria growth occurred at $37{ }^{\circ} \mathrm{C}$ until reaching the mid-log phase $\left(\mathrm{OD}_{600 \mathrm{~nm}}=0.4-0.6\right)$. After this period, the bacterial suspensions were prepared as described below and REMA assays were performed. The anti-M. tuberculosis activity of the compounds was determined by the REMA (Resazurin Microtiter Assay) method. ${ }^{20}$ Stock solutions of the tested compounds $(10 \mu \mathrm{g} / \mathrm{mL})$ were prepared in DMSO and diluted in Middlebrook 7H9 broth supplemented with $10 \%$ of OADC (OADC enrichment BBL/Becton-Dickinson, Sparks, MD, USA).
The microdilution of the compounds was performed in 96-well plates to obtain final compound concentration ranges of 0.39-100 $\mu \mathrm{g} / \mathrm{mL}$. Rifampicin in a concentration range of $0.004-1 \mu \mathrm{g} / \mathrm{mL}$ was added as control. Bacterial suspensions were prepared and their turbidities adjusted to match the optical density of McFarland No. 1 standard. After further dilution of 1:20 in the respective Middlebrook 7H9 broth supplemented with OADC, $100 \mu \mathrm{L}$ of the inoculum was added to each well of the 96-well plate. Cultures were incubated for 7 days at $37{ }^{\circ} \mathrm{C}$, and $30 \mu \mathrm{L}$ of $0.01 \%$ resazurin were added. Wells were read after $24 \mathrm{~h}$ for colour change and measured as the fluorescence (excitation/emission of $530 / 590 \mathrm{~nm}$ filters respectively) in a microfluorimeter. The MIC was defined as the lowest concentration resulting in $90 \%$ inhibition of $M$. tuberculosis growth. The presented results are from two independent experiments.

\subsection{CYP121A1 crystallography}

Untagged CYP121A1 protein and crystals were prepared as previously reported, with the following adaptations. ${ }^{30}$ Crystals were prepared using a Mosquito pipetting robot (Molecular Dimensions, Newmarket, UK) in $800 \mathrm{~nL}$ drops with protein-to-mother liquor at a ratio of $1: 1$, by vapor diffusion in $1.5-2.1 \mathrm{M}$ ammonium sulfate and $0.1 \mathrm{M}$ sodium MES or Cacodylate from pH 5.5-6.15. Co-crystals were prepared following incubation with $2 \mathrm{mM}$ ligand prepared in DMSO. Protein solutions were centrifuged at 14,000 rpm for 20 mins at $4{ }^{\circ} \mathrm{C}$ immediately before crystallogenesis. Ligand soaks were also carried out either by directly dissolving solid ligand at saturation or by the addition of a 2-5 mM ligand solution in DMSO to the mother liquor, and soaking was carried out for a minimum period of $24 \mathrm{~h}$. Crystals were immersed in mother liquor supplemented with 10-30\% oil as cryoprotectant and cryoprotected and flash-cooled in liquid nitrogen. Data were collected on beamline i02 (wavelength $0.9795 \AA$ ) at the Diamond Light Source Facility (Oxfordshire, UK). The diffraction data were reduced, scaled and merged using $\mathrm{XDS}^{31}$ or Xia2. ${ }^{32}$ Structures were refined using PHENIX $^{33}$ with the native CYP121A1 structure (PDB 1N40) ${ }^{30}$ as the starting model. Structural rebuilding and validation were performed with COOT, ${ }^{34}$ Molprobity ${ }^{35}$ and PDB REDO, ${ }^{36}$ Data collection and final refinement statistics are provided in Table 3. Images for presentation were rendered using an academic version of the PyMOL Molecular Graphics System, Schrödinger, LLC.

\subsection{Molecular modeling}

\subsubsection{Flexible alignment}

Ligands 17 and the natural substrate cYY were built using $\mathrm{MOE}^{14}$ builder, and saved in a database. Each ligand and $\mathrm{CYY}$ were extracted from the database and energy minimisation was performed using the MMFF94 forcefield. Flexible alignment was performed for each ligand with $\mathrm{CYY}$, giving an output database. The score functions were given for each pair that quantifies the quality of the alignment in terms of both internal strain and overlap of molecular features.

\subsubsection{Docking studies}

Docking studies were performed on an Intel Xenon ${ }^{\circledR}$ CPU E5462 @ $280 \mathrm{GHz} \times 4$ processors running Linux Ubuntu 12.04.1 LTS using molecular operating environment (MOE) software ${ }^{14}$ and Mtb CYP121A1 co-crystallized with the natural substrate $\mathrm{CYY}$ at a resolution of $1.4 \AA$ (PDB ID: $3 \mathrm{G} 5 \mathrm{H}$ ). All minimisations were performed with MOE to a RMSD gradient of $0.01 \mathrm{kcal} / \mathrm{mol} / \AA \AA$ with MMFF94 forcefield, and partial charges were automatically calculated. The charge of the heme iron at physiological $\mathrm{pH}$ was set to $3^{+}$(geometry d2sp3) through the atom manager in MOE. The Alpha Triangle placement, which derives poses by random superposition of ligand 
atom triplets through alpha sphere dummies in the receptor site, was chosen to determine the poses. The London $\Delta G$ scoring function estimates the free energy of binding of the ligand from a given pose. Refinement of the results using MMFF94 forcefield, and rescoring of the refined results using the London $\Delta \mathrm{G}$ scoring function was applied. The output database dock file was created with different poses for each ligand and arranged according to the final score function $(\mathrm{S})$, which is the score of the last stage that was not set to zero.

\section{Acknowledgements}

We thank the Egyptian Government for a Channel research scholarship to Hend Abd El-wahab and the EPSRC Mass Spectrometry Centre, Swansea, U.K. for mass spectroscopy data. For Leonardo Marino we thank his funders FAPESP (2011/21232-1); CNPq (140079/2013-0) and CAPES PDSE (99999.003125/201409). Andrew Munro and Kirsty McLean are grateful for support for their research through grants from the BBSRC (Grant Nos. BB/ K001884/1 and BB/I019227/1).

\section{A. Supplementary data}

Supplementary data associated with this article can be found, in the online version, at https://doi.org/10.1016/j.bmc.2017.11.030.

\section{References}

1. Dheda K, Barry CE, Maartens G. Tuberculosis. Lancet. 2015;387:1211-1226.

2. World Health Organization. Tuberculosis. Fact sheet No. 104: http://www.who. int/mediacentre/factsheets/fs104/en/ 2017 (accessed 05.08.17).

3. The National Institute for Health and Care Excellence. Tuberculosis pathway. London: NICE: http://pathways.nice.org.uk/pathways/tuberculosis 2015 (accessed 05.08.17).

4. McLean KJ, Dunford AJ, Neeli R, Driscoll MD, Munro AW. Structure, function and drug targeting in Mycobacterium tuberculosis cytochrome P450 systems. Arch Biochem Biophys. 2007;464:228-240.

5. Park DK, Lee KE, Baek $\mathrm{CH}$, et al. Cyclo(Phe-Pro) modulates the expression of ompU in Vibrio spp. J Bacteriol 2016;188:2214-2221.

6. Scopel M, Abraham WR, Henriques AT, Macedo AJ. Dipeptide cis-cyclo(leucyltyrosyl) produced by sponge associated Penicillium sp. F37 inhibits biofilm formation of the pathogenic Staphylococcus epidermidis. Bioorg Med Chem Lett. 2013:23:624-626.

7. Taubert D, Grimberg G, Stenzel W, Schömig E. Identification of the endogenous key substrates of the human organic cation transporter OCT2 and their implication in function of dopaminergenic neurons. PLoS One. 2007;2:e385.

8. Belin $\mathrm{P}$, Le Du MH, Fielding A, et al. Identification and structural basis of the reaction catalyzed by CYP121, an essential cytochrome P450 in Mycobacterium tuberculosis. Proc Natl Acad Sci USA. 2009;106:7426-7431.

9. Fonvielle M, Le Du MH, Lequin O, et al. Substrate and reaction specificity of Mycobacterium tuberculosis cytochrome P450 CYP121: insights from biochemical studies and crystal structures. J Biol Chem. 2013;288:17347-17359.

10. Vinh TK, Ahmadi M, Lopez Delgado PO, et al. 1-[(Benzofuran-2-yl) phenylmethyl]-triazoles and - tetrazoles - potent competitive inhibitors of aromatase. Bioorg Med Chem Lett. 1999;9:2105-2108.

11. Saberi MR, Shah K, Simons C. Benzofuran- and furan-2-yl-(phenyl)-3pyridylmethanols: synthesis and inhibition of P450 aromatase. J Enzyme Inhib Med Chem. 2005;20:135-141.

12. Gomaa MS, Bridgens CE, Veal GJ, et al. Synthesis and biological evaluation of 3(1H-imidazol- and triazol-1-yl)-2,2-diemthyl-3-[4-(naphthalen-2-ylamino) phenyl]propyl derivatives as small molecule inhibitors of retinoic acid 4hydroxylase (CYP26). J Med Chem. 2011:54:6803-6811.

13. Kim HJ, Kwak WY, Min JP, et al. Discovery of DA-1229: a potent, long acting dipeptidyl peptidase-4 inhibitor for the treatment of type 2 diabetes. Bioor Med Chem Lett. 2011;21:3809-3812.

14. Ott I, Kircher B, Heinisch G. Substituted pyridazino[3,4- $b][1,5]$ benzoxazepin-5 (6H)ones as multidrug-resistance modulating agents. J Med Chem. 2004; 47:4627-4630.

15. Zhang C, Tan $\mathrm{C}, \mathrm{Zu} \mathrm{X}$, et al. Exploration of (s)-3-aminopyrrolidine as a potentially interesting scaffold for discovery of novel abl and pi3k dual inhibitors. Eur J Med Chem. 2011;46:1404-1414.

16. Das S, Das VK, Saikia L, Thakur AJ. Environment-friendly and solvent-free synthesis of symmetrical bis-imines under microwave irradiation. Green Chem Lett Rev. 2012;5:457-474.

17. Sharma V, Khan MSY. Synthesis of novel tetrahydroimidazole derivatives and studies for their biological properties. Eur J Med Chem. 2001;36:651-658.

18. McLean KJ, Marshall KR, Richmond A, et al. Azole antifungals are potent inhibitors of cytochrome P450 mono-oxygenases and bacterial growth in mycobacteria and streptomycetes. Microbiology. 2002;148:2937-2949.

19. Korzekwa KR, Krishnamachary N, Shou M, et al. Evaluation of atypical cytochrome P450 kinetics with two-substrate models: evidence that multiple substrates can simultaneously bind to cytochrome P450 active sites. Biochemistry. 1998:37:4131-4147.

20. Palomino JC, Martin A, Camacho M, Guerra H, Swings J, Portaels F. Resazurin microtiter assay plate: simple and inexpensive method for detection of drug resistance in Mycobacterium tuberculosis. Antimicrob Agents Chemother. 2002;46:2720-2722.

21. Ghose AK, Crippen GM. Atomic physicochemical parameters for threedimensional-structure-directed quantitative structure-activity relationships. 2. Modeling dispersive and hydrophobic interactions. J Chem Inf Comput Sci. 1987;27:21-35.

22. Molecular Operating Environment (MOE), 2013.08; Chemical Computing Group Inc., 1010 Sherbooke St. West, Suite \#910, Montreal, QC, Canada, H3A 2R7, 2016.

23. Hudson SA, McLean KJ, Surade S, et al. Application of fragment screening and merging to the discovery of inhibitors of the Mycobacterium tuberculosis cytochrome P450 CYP121. Angew Chem Int Ed. 2012:51:9311-9316.

24. Kavanagh ME, Gray JL, Gilbert SH, et al. Substrate fragmentation for the design of M. tuberculosis CYP121 inhibitors. ChemMedChem. 2016;11:1924-1935.

25. Seward HE, Roujeinikova A, McLean KJ, Munro AW, Leys D. Crystal structure of the Mycobacterium tuberculosis P450 CYP121-fluconazole complex reveals new azole drug-P450 binding mode. J Biol Chem. 2006;281:39437-39443.

26. Cole ST, Brosch R, Parkhill J, et al. Deciphering the biology of Mycobacterium tuberculosis from the complete genome sequence. Nature. 1998:393:537-544.

27. Butts CP, Jazdzyk MDS. Piperazine additions to C60-a facile approach to fullerene substitution. Org Biomol Chem. 2005;3:1209-1216.

28. Li Y, Bacon K, Sugimoto H, Fukushima K, Hashimoto K, Marumo M, Moriwaki T, Nunami N, Tsuno N, Urbahns K. 2-Phenoxy- and 2-phenylsulfomamide derivatives with ccr3 antagonistic activity for the treatment of asthma and other inflammatory or immunological disorders. WO2004084898 A1; 2004.

29. Boyce RS, Phillips J, Speake JD. Quinazolinone compounds with reduced bioaccumulation. WO2005051391 A1; 2005.

30. McLean KJ, Carroll P, Lewis DG, et al. Characterization of active site structure in CYP121. A cytochrome P450 essential for viability of Mycobacterium tuberculosis. H37Rv. J Biol Chem. 2008;283:33406-33416.

31. Kabsch W. XDS. Acta Crystallogr D Biol Crystallogr. 2010;66:125-132.

32. Winter G. (2010) Xia2: an expert system for macromolecular crystallography data reduction. J Appl Crystallogr. 2010;43:186-190.

33. Adams PD, Afonine PV, Bunkóczi G, et al. Phenix: A comprehensive pythonbased system for macromolecular structure solution. Acta Crystallogr D Biol Crystallogr. 2010;66:213-221.

34. Emsley P, Lohkamp B, Scott WG, Cowtan K. Features and development of Coot Acta Crystallogr D Biol Crystallogr. 2010;66:486-501.

35. Chen VB, Arendall 3rd WB, Headd JJ, et al. MolProbity: all-atom structure validation for macromolecular crystallography. Acta Crystallogr D Biol Crystallogr. 2010;66:12-21.

36. Joosten RP, Long F, Murshudov GN, Perrakis A. The PDB_REDO server for macromolecular structure model optimization. IUCrJ. 2014;1:213-220. 